NBER WORKING PAPER SERIES

\title{
EFFECT OF HEALTH INSURANCE IN INDIA: A RANDOMIZED CONTROLLED TRIAL
}

\author{
Anup Malani \\ Phoebe Holtzman \\ Kosuke Imai \\ Cynthia Kinnan \\ Morgen Miller \\ Shailender Swaminathan \\ Alessandra Voena \\ Bartosz Woda \\ Gabriella Conti \\ Working Paper 29576 \\ http://www.nber.org/papers/w29576
}

\author{
NATIONAL BUREAU OF ECONOMIC RESEARCH \\ 1050 Massachusetts Avenue \\ Cambridge, MA 02138 \\ December 2021
}

We thank Kate Baicker, Amitabh Chandra, Pascaline Dupas, Johannes Haushofer, Rick Hornbeck, Joe Newhouse, Neale Mahoney, Julian Reif, Joshua Gottlieb, and seminar participants at Brown University, University of Chicago, Harvard, and Stanford for comments. This study was funded by the Department for International Development in the UK Government; the Tata Trusts through the Tata Centre for Development at the University of Chicago; the MacLean Center, the Becker-Friedman Institute, the Neubauer Collegium, and the Law School at the University of Chicago; the Sloan Foundation; SRM University; and the International Growth Centre. The views expressed herein are those of the authors and do not necessarily reflect the views of the National Bureau of Economic Research.

NBER working papers are circulated for discussion and comment purposes. They have not been peer-reviewed or been subject to the review by the NBER Board of Directors that accompanies official NBER publications.

(C) 2021 by Anup Malani, Phoebe Holtzman, Kosuke Imai, Cynthia Kinnan, Morgen Miller, Shailender Swaminathan, Alessandra Voena, Bartosz Woda, and Gabriella Conti. All rights reserved. Short sections of text, not to exceed two paragraphs, may be quoted without explicit permission provided that full credit, including $\odot$ notice, is given to the source. 
Effect of Health Insurance in India: A Randomized Controlled Trial

Anup Malani, Phoebe Holtzman, Kosuke Imai, Cynthia Kinnan, Morgen Miller, Shailender

Swaminathan, Alessandra Voena, Bartosz Woda, and Gabriella Conti

NBER Working Paper No. 29576

December 2021

JEL No. I13,O1

\section{ABSTRACT}

We report on a large randomized controlled trial of hospital insurance for above-poverty-line Indian households. Households were assigned to free insurance, sale of insurance, sale plus cash transfer, or control. To estimate spillovers, the fraction of households offered insurance varied across villages. The opportunity to purchase insurance led to 59.91\% uptake and access to free insurance to $78.71 \%$ uptake. Access increased insurance utilization. Positive spillover effects on utilization suggest learning from peers. Many beneficiaries were unable to use insurance, demonstrating hurdles to expanding access via insurance. Across a range of health measures, we estimate no significant impacts on health.

Anup Malani

University of Chicago

Law School

1111 E. 60th Street

Chicago, IL 60637

and NBER

amalani@uchicago.edu

Phoebe Holtzman

Jones Lang LaSalle

330 Madison Ave 4th floor

New York, NY 10017

phoebe.holtzman@am.JLL.com

Kosuke Imai

Harvard University

1737 Cambridge Street

Cambridge, MA 02138

imai@harvard.edu

Cynthia Kinnan

Department of Economics

Tufts University

8 Upper Campus Road

Medford, MA 02155

and NBER

cynthia.kinnan@tufts.edu

Morgen Miller

University of Chicago

Law School

1111 E. 60th St.

Chicago, IL 60637

mmmiller@uchicago.edu
Shailender Swaminathan

Sai University

SSPDL Building,

Beta Block 4th Floor Navalur

Old Mahabalipuram Rd

Chennai

India

shailender.s@saiuniversity.edu.in

Alessandra Voena

Stanford University

Landau Economics Building

579 Jane Stanford Way

Stanford, CA 94305

and NBER

avoena@stanford.edu

Bartosz Woda

University of Chicago

Law School

1111 E. 60th St.

Chicago, IL 60637

woda@uchicago.edu

Gabriella Conti

Department Of Economics

University College London London

gabriella.conti@ucl.ac.uk 
Household financing of healthcare in lower middle-income countries like India is challenging. In 2018, while $11 \%$ of health expenditures were paid by households out-of-pocket in the US, 62\% were in India (World Health Organization 2021). Moreover, many households are pushed into poverty by health costs, and care is often foregone due to cost concerns (Berman and Ahuja 2008). To address these concerns, the Indian government in 2008 launched Rashtriya Swasthya Bima Yojana (RSBY), a hospital-insurance program for below-poverty-line households in India. Of roughly 280 million people eligible, 170 million enrolled. In 2018 India replaced RSBY with Pradhan Mantri Jan Arogya Yojana (PMJAY), a plan covering 537 million - all below-poverty-line persons plus nearly 260 million above-poverty-line people.

Both RSBY and its replacement provided insurance largely for free. This decision was based, in part, on the concern that cost-sharing would reduce enrollment (Cohen and Dupas 2010). Utilization, even under the new scheme, has not been high (Garg, Bebarta et al. 2020), and government health expenditure remained just 1\% of GDP in 2018 (World Health Organization 2021). Had utilization been high, the fiscal cost would have been much greater, a common criticism of publicly-financed health-insurance schemes in countries with low fiscal capacity (Oxfam 2008). Moreover, the health impacts of utilization are poorly understood. This experience raises a number of questions.

First, why was utilization low? Whereas health insurance has been common in the US since the 1940s (Patel and Rushefsky 2019), it spread in India only after 2000 (La Forgia and Nagpal 2012). As with other new technologies, individuals (and hospitals) may not know how to use this product. Adoption may be slow and subject to learning by doing or spillovers as individuals learn from other users (Sorensen 2006, Liu, Sun et al. 2014).

Second, could lower-income countries like India reduce pressure on public finances, without compromising uptake, by offering the opportunity to buy insurance without subsidies (i.e., pure insurance)? This policy would be closer to what the individual insurance market offers, and what the US Affordable Care Act does on insurance exchanges (though that program also subsidizes premiums). Offering free insurance, as PMJAY and U.S. Medicaid do, is equivalent to offering pure insurance plus a conditional subsidy equal to the full premium.

Third, does health insurance improve health in lower-income countries? Randomized controlled trials in the US provide mixed results. Some find few significant effects (Newhouse 1993, Baicker, Taubman et al. 2013) while others report large mortality benefits (Goldin, Lurie et al. 2019). ${ }^{1}$ But the US experience may not apply to lower-income countries. Randomized

\footnotetext{
${ }^{1}$ The quasi-empirical literature in the US is similarly split. See the review in Levy \& Meltzer (2008) and more recently, e.g., Sommers et al. (2014), Black et al. (2017), Huh et al. (2017), Miller et al. (2021), Abaluck et al. (2021), and Chandra et al. (2021).
} 
evaluations in low and middle-income countries occasionally find effects on utilization, but none finds a significant effect on health (King, Gakidou et al. 2009, Thornton, Hatt et al. 2010, Levine, Polimeni et al. 2016, Haushofer, Chemin et al. 2020). India's experience might differ because the country has fewer safety nets than the US, is less urban and has different disease burdens than many emerging economies, and has poor quality health care (Das, Holla et al. 2012, Mohanan, Vera-Hernández et al. 2015, Naghavi, Abajobir et al. 2017). One prior randomized study in New Delhi was conducted early in the roll-out of RSBY, so may not reflect the mature or long-term impact of that program (Das and Leino 2011). Another study in the state of Karnataka found large mortality effects, but was not a randomized controlled trial (Sood, Bendavid et al. 2014).

To address the questions above, we conducted a large randomized controlled trial from 2013-2018 to study the impact of expanding hospital insurance eligibility under RSBY, an expansion subsequently implemented in its successor program, PMJAY. The study was conducted in Karnataka, which spans south to central India. The sample included 10,879 households (comprising 52,292 members) in 435 villages. Sample households were above the poverty line, not otherwise eligible for RSBY, and lacked other insurance.

To tease out the effects of different options for providing insurance, sample households were randomized to one of four treatments: free RSBY insurance, the opportunity to buy RSBY insurance, the opportunity to buy plus an unconditional cash transfer equal to the RSBY premium, and no intervention. To understand the role spillovers play in insurance utilization, we varied the fraction of sample households in each village that were randomized to each insurance-access option. The intervention lasted from May 2015 to August 2018.

We conducted a baseline survey involving multiple members of each household 18 months before the intervention. We measured outcomes two times, at 18 months and at 3.5 years post intervention. The latter survey addressed concerns that the longer-term effects of insurance may differ from the short-term effects, due to, e.g., learning-by-doing, the accumulation of health benefits from medical care (Black, Espín-Sánchez et al. 2017), negative experiences that lead households to stop utilizing insurance, or crowd-out or congestion that builds up over time.

We estimate two treatment effects: an intent-to-treat (ITT) effect that measures the average impact of giving a household access to insurance and a treatment on treated (TOT) effect that measures the average impact of insurance uptake on a household. The latter is estimated by using our randomization to various forms of insurance access as instruments for uptake.

Our primary finding is that sale of insurance achieves three-quarters the uptake that free insurance does. The option to buy RSBY insurance increased uptake to $59.91 \%$ (ITT). The 
unconditional cash transfer increased utilization to $72.24 \%$ and the conditional subsidy (i.e., free insurance) to $78.71 \%$. The additional uptake from conditional subsidies implies a price elasticity of insurance demand of -0.314 , in line with the literature (Pendzialek, Simic et al. 2016). While conditional subsidies do have a sizable effect on enrollment, the cost to the government of the incremental 18.8 percentage point ( $p p$ ) gain is roughly 4 times the premium because uptake of pure insurance is so high.

Our second finding is that insurance increased utilization, but many beneficiaries were unable to use their insurance and the utilization effect dissipated over time. Access to free insurance, e.g., increased 6-month utilization of insurance by $6.73 \mathrm{pp}$ over a control group mean of $3.86 \%$ at 18 months (ITT). Enrollment in insurance raised utilization 6.02 pp over the control group mean of $3.88 \%$ at 18 months (TOT). However, many enrolled households were unable to use insurance to cover the costs of health care: $5.01 \%$ of enrolled households tried but were unable to use their insurance card (compared to a control group failure rate of $1.50 \%) .^{2}$ This may reflect not just supply-side constraints, but also demand-side obstacles such as households forgetting their card or trying to use RSBY at non-participating hospitals. The failure rate was lower amongst those who paid for insurance, which may indicate that prices screen for more knowledgeable, higher value users, lead to a "sunk cost", or signal quality in a manner that increases successful use. ${ }^{3}$ In addition, utilization fell over time: 6-month utilization was just $1.60 \%$ in the free-insurance group after 3.5 years. Instead of learning-by-doing, perhaps households were disappointed by the difficulty of using the new insurance product.

Our third finding is that spillovers play an important role in promoting insurance utilization. The magnitude of spillover effects is roughly twice that of direct effects in the freeinsurance arm at 18 months. Without those spillover effects, overall ITT utilization effects would not be statistically significant. This is consistent with other findings in the literature on insurance utilization (Sood, Bendavid et al. 2014) and suggests peer effects may play a role in learning how to utilize insurance.

Our final finding is that health insurance showed statistically significant treatment effects on only 3 outcomes among 82 health-related outcomes across 2 waves of surveying. However, we cannot rule out clinically-significant health effects, on average equal to $11 \%$ $(8.8 \%)$ of the standard deviation for each health outcome in ITT (TOT) analyses. Therefore, even this study, which is amongst the largest health insurance experiments ever conducted,

\footnotetext{
${ }^{2}$ Our finding of failure during attempts to use insurance complements Banerjee et al. (2021), which documents failure during attempts to obtain insurance in Indonesia.

${ }^{3}$ In a companion paper (Kinnan et al. 2021) we investigate another possible mechanism underlying more utilization among the paid group, namely adverse selection. However, we show that, while detectable, the degree of adverse selection is small.
} 
may not be powered to estimate the health effects of insurance (Goldin, Lurie et al. 2019, Kaestner 2021).

The following is a roadmap for the remainder of this paper. Section I presents our methods. Section II presents our results. Section III concludes with a comparison of our findings and the existing literature on the impact of health insurance in low- and middle-income countries.

\section{Methods}

\section{A. Setting}

India's population obtains $75 \%$ of its care from private facilities (Government of India and Ministry of Health and Family Welfare 2014-2015). Before 2008, only 75 million people had health insurance (Prinja, Bahuguna et al. 2019). Uninsured patients pay out-of-pocket for care. If patients lack money to pay for care, a private hospital may deny care. Patients can obtain subsidized care at public facilities. However, these facilities have limited inventories of consumables such as anesthetics (Deka 2012, Nair 2018), which patients must buy themselves. Over 60 million Indians annually are impoverished by healthcare expenditures (Shahrawat and Rao 2012).

From 2008 to 2018, the Indian government, under the RSBY program and apart from the study, paid private companies to provide health insurance to below-poverty-line households and certain vulnerable occupations. (The poverty line in Karnataka in 2012 was annual income of ₹54,120 $(\$ 3,089.04)$ in rural and $₹ 65,340(\$ 3,729.45)$ in urban areas for a family of 5 (Prabhavathi and Naveena 2014).) The government paid an annual premium in 2015 of ₹133 (\$7.59) and ₹173 (\$9.87) per household in Gulbarga and Mysore, respectively, the two districts of Karnataka in our study. ${ }^{4}$ (We employ the ₹17.52/dollar purchasing-power-parity exchange rate (OECD 2020).) RSBY insurance covered inpatient treatments, select outpatient surgeries, and diagnostic tests and at in-network public and, importantly, private hospitals. It did not cover primary care. The government alone was responsible for enrolling eligible households via occasional enrollment campaigns and at RSBY offices. Although the government paid premiums, households paid ₹30 (\$1.71) for an insurance card. Insurance coverage had no deductible or copay, but had an annual cap (₹30,000,\$1,712.33) per household. The government dictated prices for procedures; this cap was enough to cover, e.g., 4 c-sections or $10 \mathrm{MRIs}$. Up to 5 members per household were covered.

\footnotetext{
${ }^{4}$ The premium the government paid was low because the hospital utilization rate of below-poverty-line household is low and the government buys insurance from the insurance company bidding the lowest premium.
} 


\section{B. Participants}

The study was conducted in Mysore and Gulbarga districts, representative of south and central India, respectively. Villages within $25 \mathrm{~km}$ of an in-network hospital in 2013 were included to ensure hospitals were accessible. Households were included if a member had an official card indicating they were above the poverty line but were excluded if anyone had a below-poverty-line card, RSBY coverage or other hospital insurance. The Appendix provides more details about sample composition, study design and data collection. Recruitment, randomization and follow-up are described in Figure $A 1$.

\section{Intervention and randomization}

The study offered sample households, which were not otherwise eligible for insurance under RSBY, access to insurance under that scheme. Specifically, sample households were assigned to one of 4 groups: (A) access to RSBY for free ("free insurance"), (B) the opportunity to purchase RSBY ("sale of insurance") plus an unconditional cash transfer ("transfer") equal to the purchase price, (C) the opportunity to purchase RSBY ("pure insurance"), or (D) no intervention. Households assigned to arm A did not have to pay the RSBY premium or the fee for an insurance card. The purchase price for groups $B$ and $C$ was the premium plus the fee. The transfer to B was the premium plus the fee. Study households that enrolled in RSBY received coverage from May 2015 to August 2018. Because eligibility for RSBY was an exclusion criterion, group D had no access to RSBY at the start of the study.

To estimate spillover effects, e.g., whether the effects of insurance access vary with the share of village households given access, we varied across villages the fraction of sample households provided insurance access.

We generated village- and household-level variation in insurance access by employing a two-stage randomization design (Hudgens and Halloran 2008) (Figure A2). In stage one, we created blocks of villages based on village-level variables (sample population and averages of age, education of head of household, number of children in a household, number of rooms in a house, whether head of household was employed, and whether someone in the household had a major illness last year). We randomized villages within each block to one of five conditions: each with different shares of households allocated to groups A to D. In stage two, within each village, we created blocks of households based on household-level analogues to the village averages used to block villages. We randomized households to groups $A$ to $D$ based on the allocation to which their village was assigned. Village-level conditions involved $50 \%, 30 \%$ or $10 \%$ of sample households assigned to the control group. Overall, roughly $40 \%$ of households were assigned to group A and $20 \%$ to every other group. Figure A4 reports that our ultimate assignment is balanced on baseline outcomes.

\section{Outcomes}


Our primary outcomes were insurance and hospital utilization at 18 months (midline) and 3.5 years (endline) after insurance access. Secondary outcomes included insurance enrollment; other utilization metrics, such as the inability to use insurance and outpatient surgeries (endline only); and multiple categories of health. Each category included multiple individual indicators: self-reported health (1 category at midline, 2 at endline), objective health indicators ( 7 midline), chronic disease (15 midline, 17 endline), quality of life (1 midline, 14 endline), mental health ( 3 endline), childbirth ( 8 midline, 10 endline), and mortality ( 4 endline). A final secondary health outcome was an index of health, following Kling, Liebman et al. (2007), equal to the average of z-scores for individual health outcomes.

Approximately 18 months prior to the intervention (Figure A3), we conducted a baseline survey of several members in each sample household: the male head of household, a female knowledgeable about household finances, and a female with children below age 18 . Those surveys asked about finances and self-reported health. In addition, we selected a random onethird of sample households and conducted a biomarker survey that gathered objective health measures on three members: the male most knowledgeable, a woman of childbearing age, and a child under the age 18 if available). At 18 months after the intervention, we conducted a midline survey similar to baseline, including the biomarker survey. At 3.5 years after the intervention, we conducted an endline survey of one household member, the male head or a female knowledgeable about household finances. We did not conduct the biomarker survey at endline. Because the intervention ended 6 months before our endline, we asked the respondent to recall hospital utilization 6 months before a notable holiday that occurred just before the intervention ended. In all surveys we approached the same households and endeavored to interview the same persons.

Measured outcomes varied across surveys. Table A1 lists outcomes measured, by topic, at midline and endline. We distinguish between insurance use (the use of RSBY to pay for hospital care) and hospital care (the actual consumption of health care). Definitions of different health scores are in the Appendix.

\section{E. Sample size and power}

Our target sample size, 2,250 households per group, ensured $80 \%$ power to detect a $25 \%$ change in hospitalization rate across groups at the $5 \%$ significance level, allowing for $10 \%$ attrition and assuming a hospitalization rate in the control group of $10.5 \%$ and $11.8 \%$ in Mysore and Gulbarga (National Sample Survey Organisation 2004), respectively. We doubled the sample size for the free-insurance group to increase power for the most likely form for any future insurance expansion.

\section{F. Estimation of treatment effects}


We report intent-to-treat (ITT) estimates of the effect of different methods of access to RSBY on enrollment, and both ITT and treatment-on-treated (TOT) estimates of the effect of enrollment in RSBY on utilization and health at 18 months and 3.5 years.

Intent-to-treat. ITT estimates were based on the following linear regression:

$$
y_{i j t}=\alpha+\sum_{h=1}^{3} \beta_{h} d_{i j}^{h}+\delta s_{j}+\sum_{h=1}^{3} \gamma^{h} d_{i j}^{h} s_{j}+\zeta X_{i j}+\epsilon_{i j t}
$$

where $i, j$ and $t$ index households, villages and time, respectively; $y_{i j t}$ is an outcome, $d_{i j}^{h}$ is an indicator for assignment household-condition $h$ with $(h=1=A, 2=B, 3=C) ; s_{j}$ is the share of the sample in village $j$ that is in household conditions A, B or C; and $\epsilon_{i j t}$ is an error term. We accounted for spillover effects at the village level by examining the predicted effects on outcomes for a household in a given household condition at different shares of the village sample in that condition. If the share given access lay between $50-90 \%$, it was within the range observed in the sample. In order for the estimate of spillover effects to be unbiased, it was assumed that assignment in villages $j^{\prime} \neq j$ do not influence outcomes in another village $j$ (partial non-interference) (Imai, Jiang et al. 2019). The cluster robust HC2 standard error was used to cluster at the village level, which is conservative (Imai, Jiang et al. 2019).

The average direct effect of providing access to insurance via arm $h$ to a given household was estimated as the coefficient $\beta_{h}$ on the indicators $d_{i j}^{h}$. The average spillover or indirect effect on a given household in arm $h$ of providing other households in a village access to insurance via any arm, i.e., the spillover effects of any insurance access, was estimated as the sum of (a) the coefficient on the share $s_{j}$ of the sample in the village in any arm and (b) the coefficient on the interaction between the household arm indicator and the share variable, $d_{i j}^{h} s_{j}$. This interaction allows for the spillover to vary depending on the arm $h$ to which a household is assigned.

The total effect of providing access to all sampled households in a village is the sum of (a) direct effects and (b) indirect effects times the share of other sample households in a village that are offered insurance. We report total effects assuming this share is $90 \%$. A more realistic scenario is $100 \%$ because a future insurance expansion will likely cover all other sample-eligible households. However, we choose $90 \%$ because no village arm offered more than $90 \%$ of sample households insurance, so reporting $100 \%$ would be an out-of-sample prediction.

For binary outcomes we used a linear probability model (LPM). For our ITT analysis we contrasted the LPM results with those obtained from a logistic model, but did not find economically- or clinically-significant differences between the two models.

Treatment-on-treated. An instrumental variables approach was used to estimate the TOT effect of RSBY enrollment. This corresponds to a "complier average treatment effect" 
effect of enrolling in RSBY. This estimate was obtained from a regression with a two-stage least squares structure where the second stage regression is

$$
y_{i j t}=\alpha+\phi r_{i j}+\theta z_{j}+\rho r_{i j} z_{j}+\psi X_{i j}+u_{i j t}
$$

where $r_{i j}$ is an indicator for RSBY enrollment and $z_{j}$ is the share of the sample in village $j$ that enrolled in RSBY. We instrumented for $\left(r_{i j}, z_{j}, r_{i j} z_{j}\right)$ using variables $\left(d_{i j}^{h}, d_{j}^{v}, d_{i j}^{h} d_{j}^{v}\right)$, where $d_{j}^{v}$ is an indicator for assignment to village-level arm $v$ for $v \in(I, I I, I I I, I V, V)$. Weighting, controls, and standard errors were handled in the same way as with the ITT estimator. The exclusion restriction was that treatment assignment only affects household outcomes through the decision to enroll in RSBY. To obtain unbiased estimates of spillovers, we assumed partial noninterference, as under ITT, and that, for non-compliers, their treatment assignment did not affect their outcomes through the enrollment of other units (Imai, Jiang et al. 2019).

The TOT estimate of the (direct) effect of enrolling a given household was estimated using the coefficient on enrollment. The average (indirect) effect on a given enrolled household of enrolling other households in a village, i.e., the spillover effect, was estimated using the coefficients on the share enrolled and the interaction of share and the indicator for household enrollment. The total effect of enrolling all sample households in a village was estimated by summing (a) the direct effect and (b) the indirect effect of moving the percent of a village sample that was enrolled from $0 \%$ to $78.71 \%$, the maximum uptake in any arm accounting for in-sample spillover effects. The cluster robust HC2 standard error is used to cluster at the village level and account for the two-stage randomization design.

Both ITT and TOT analyses weighted households equally. Because males and females were asked the same health questions at 18 months, we present estimates of a common effect across sexes.

We consider two sets of options for $p$-values. To test hypotheses pertaining to groups of related outcomes, we primarily report critical p-values for those groups using a multipletesting correction procedure (Benjamini and Yekutieli 2001) to control the false discovery rate. Second, we present $p$-values for individual outcomes because all endline outcomes were prespecified in our analysis plan.

\section{Results}

\section{A. Study population}

Non-response rates were reasonably low. Non-response (attrition) rates for our main surveys averaged $5 \%(0.2 \%)$ at baseline, $4 \%(3 \%)$ at 18 months, and $13 \%$ at 3.5 years. The biomarker surveys' non-response rates average $17 \%$ at baseline and $24 \%$ at 18 months (Table 
A2). ${ }^{5}$ We cannot reject the null hypothesis that non-response was identical across treatment arms.

Table 1 presents characteristics of respondent households by group at baseline. The mean annual household budget (excluding medical expenditures) across groups was ₹98,326 $(\$ 5,618.63)$. (For reference, the poverty line in Karnataka in 2012 was annual income of $₹ 54,120(\$ 3,089.04)$ in rural and $₹ 65,340(\$ 3,729.45)$ in urban areas for a family of 5 (Prabhavathi and Naveena 2014).) Mean medical expenditure across groups was ₹38,115 $(\$ 2,191.78)$, of which ₹8,147 (\$465.01) was spent on hospital care.

\section{B. Insurance enrollment}

An important question in the policy debate around health insurance is the extent to which it is demanded at positive prices. We found, in the context of RSBY, that the enrollment rate in the group offered pure insurance, i.e., access to insurance for a premium, was relatively high. Whereas the no-intervention group had no enrollment by construction, the pure insurance group had an enrollment rate of $59.91 \%(p<0.001)$. This rate is higher than among below-poverty-line households in the RSBY scheme (43.12\% in Gulbarga, 59.97\% in Mysore (RSBY 2018)) even though those households were offered free insurance. ${ }^{6}$

Although we find a higher demand for sold insurance in our study of above-poverty-line households than there was for free insurance among below-poverty-line households in the main RSBY program, it is unlikely that the difference is driven by the higher income in our sample. A regression of uptake in the sold-insurance arm on household income yields an insignificant slope (Table A4). An alternative explanation is additional marketing. While we used the same marketing material that the usual RSBY scheme did, our study went a step further and visited each house in person to tell them where the enrollment station was on the designated day(s) of enrollment. However, we cannot test this theory as we do not have a control group.

Enrollment was 12.33 percentage points $(p p)$ higher $(p<0.001)$ in the arm that offered a cash transfer equal to the premium (72.24\%) than in the sale-of-insurance arm (59.91\%). This implies a marginal propensity to consume (MPC) insurance of $30.76 \% .^{7}$ Interpreted as a pure MPC for insurance, this is unrealistically high: per capita incomes increased by more than RSBY premiums or even private insurance premiums over the last decade, yet India's out of pocket

\footnotetext{
${ }^{5}$ Table A3 reports response rates per survey module in the main text. Female respondents typically had higher response rates than males.

${ }^{6}$ Even in the US, enrollment rates in Medicaid among eligible person is only $62 \%$ in 2008 (Sommers \& Epstein 2010). It may be lower in RSBY because insurance is a newer product in India.

$712.33 \mathrm{pp} / 40.09 \%$ that do not consume under sale of insurance $=30.76 \%$.
} 
spending rate hovered around $25 \%$ during that period. We hypothesize that the high MPC for insurance reflects in part a true MPC and in part goodwill towards the surveyors providing cash, goodwill that manifested in buying the insurance that the surveyors were also selling. Relatedly, the high apparent MPC may reflect a "flypaper effect" (Hines and Thaler 1995).

Enrollment rates were $18.80 \mathrm{pp}(\mathrm{p}<0.001)$ higher with free insurance $(78.71 \%)$ than for sale of insurance (59.91\%). This increase in enrollment in the free-insurance group and the premium for RSBY implies that the price elasticity of demand for insurance is $-0.314^{8}$, well within the range of estimates in the literature (Pendzialek, Simic et al. 2016).

Our findings have two implications for insurance policy. First, because free insurance is akin to pure insurance plus an in-kind subsidy, we infer that in-kind subsidies increase enrollment by nearly a third. In-kind subsidies are nearly twice as effective as unconditional cash transfers of the same amount $(p<0.001)$. However, ignoring concerns about distribution, pure insurance is a much more cost-effective means for the government to promote uptake than free insurance. In our sample, the government was able to pay no premiums and achieve $59.91 \%$ enrollment. ${ }^{9}$ To increase enrollment by 18.80 pp would require paying premiums for even infra-marginal households-all told, $78.71 \%$ of households. This implies an effective premium roughly 4 times the actual premium per marginal (i.e., incremental free-insurancecomplier) household.

Spillover effects in enrollment are not statistically significant (Table 2). Prior to enrollment, households were given roughly 2-weeks notice about the household-arm to which they were assigned. Although it is possible that households communicated, so there could be spillovers, we find that these spillover effects were not statistically significant.

\section{Insurance and healthcare utilization}

Our ITT estimates suggest that access to insurance substantially increased utilization of insurance for payment (Table 3). Access increased successful use of insurance at 18 months and 3.5 years in all arms. ${ }^{10}$ Because we measure utilization over the last 6 months, the annualized

${ }^{8}(78.71 \%$ enrollment with free insurance $-59.91 \%$ enrollment with sale of insurance $) / 59.91 \%=0.314$. We do not use the usual arc elasticity formula, which normalizes by the midpoint of enrollment and price, because our change in price is going from full price to zero price. Our formula implies this is a $100 \%$ reduction in price while the usual arc elasticity formula would imply this is a nonsensical $200 \%$ reduction in price.

${ }^{9}$ There is, however, a concern that, by requiring households to pay premiums, the risk pool will become more adversely selected. A companion paper (Kinnan et al. 2021) shows that the degree of adverse selection in this context is small.

${ }^{10}$ We find that access significantly affects healthcare utilization when measured by use of insurance but not when measured by hospital use. We believe this is due to the fact that the definition of hospital is ambiguous. This is evidenced by the difference between hospitalization rates in the control group and in government surveys. 
rate is double our estimates if rates are constant over a year. So, the average annual utilization rate at 18 months (3.5 years) is $13.46 \%(2.56 \%)$ in the free-insurance arms versus $7.72 \%(0.64 \%)$ in the control arm. On average this effect amounts to a $74.35 \%(400 \%)$ increase in utilization at 18 months (3.5 years). ${ }^{11}$

Our TOT estimates suggest that enrollment in insurance also increased use of insurance for payment (Table 4). Enrollment raised annual utilization at 18 months to $12.04 \%$ (from a base of $7.76 \%$ ) and at 3.5 years (for the most serious event) to $3.04 \%$ (from a base of $0.98 \%$ ).

Spillovers play an important role in boosting utilization. At 18 months and 3.5 years, ITT estimates of the direct effects of insurance access are not significant. Only the TOT estimate of direct effects on insurance use at 3.5 years is significant. Therefore, indirect effects, even though they too are insignificant, are critical for generating the significant total effects estimated for several utilization measures. These spillovers are consistent with people learning about the value of insurance via word-of-mouth from neighbors, as reported in a prior study of insurance in Karnataka (Sood, Bendavid et al. 2014).

Many households had difficulty using insurance to pay for healthcare. On average across treatment arms, access to insurance increased by $3.34 \mathrm{pp}$ annually the number of households who tried to use their insurance card by 18 months but were unable to do so (from a base of $2.68 \%$ in the control group ${ }^{12}$ ). (Our TOT estimates suggest that insurance enrollment increased failed use by $4.02 \mathrm{pp}$ off a base of $3 \%$ annually.) This excess failure rate is $50.50 \%$ of the successful utilization ITT effect.

Lack of knowledge about the purpose of insurance and how to use insurance seem likely explanations for the failure rate. Because insurance is a relatively new product, hospitals and beneficiaries may not know how to use it (Rajasekhar, Berg et al. 2011, Nandi, Dasgupta et al. 2016). In our midline and endline surveys, we asked why households did not try to use their insurance card to pay for care and why they were unable to use the card even when they tried (Table A5). Frequent reasons given for not using the card were not knowing that the card could be used for insurance (15\% at 18 months, $20 \%$ at 3.5 years), forgetting the card at home (13\%

Ethnographic work we conducted before the midline suggests that individuals refer even to clinics as hospitals. We also observe variation in rates as we change the way we ask the hospitalization question.

${ }^{11}$ It may seem strange that utilization is positive in the no-intervention arm given they were excluded if they were eligible for RSBY and did not get insurance through the study. However, we only screen if the households were eligible for RSBY at baseline. It is possible households obtained RSBY coverage in the interim, e.g., by obtaining a BPL card or switching into an RSBY-eligible occupation.

${ }^{12}$ Although no household in the control enrolled at baseline, some households in that group may have fallen below the poverty line and become eligible for RSBY by midline. 
at 18 months), not knowing how or where to use the card (29\% and $30 \%$ at 3.5 years). Besides these beneficiary-side problems, there were also supply-side problems. Of people that tried to use the card, $55 \%$ and $69 \%$ said that the doctor did not accept the card at 18 months and 3.5 years, and $12 \%$ said that the insurance company did not accept the card (i.e., did not approve use) at 3.5 years. (These should be interpreted with caution because we do not know if doctors correctly did not approve the card because a service was truly not covered, or incorrectly did so. ${ }^{13}$ ) This finding suggests that demand-side education and supply-side logistics may be important for raising utilization of (and thus demand for) insurance in India and similarly situated countries. ${ }^{14}$

\section{Health outcomes}

Access to insurance had few significant effects on health in either survey (Table 5). Having measured (a) 3 parameters (direct/indirect/total) for (b) 3 ITT and one TOT effect for (c) 82 specified outcomes over 2 surveys, only 3 (0.46\% of all estimated coefficients concerning health outcomes) were significant after multiple-testing adjustments. (As Table A8 shows, 55 parameters (8.38\%) are significant if we do not adjust for multiple-testing.) We cannot reject the hypothesis that the distribution of $p$-values from these estimates is consistent with no differences $(P=0.31)$. We also find no effect of access on our summary index of health outcomes (Table A6 and Table A7).

Care should be taken in interpreting the insignificant health effects observed. Perhaps the effect of hospital care on measured outcomes is too small to translate into health improvements that we have power to detect despite our substantial sample size (Das, Hammer et al. 2008). Moreover, confidence intervals reported in Table A6 and Table A7 suggest that medically significant effects for many outcomes cannot be ruled out. On average, the absolute value of an estimated ITT (TOT) effect for an outcome equals $11 \%(8.8 \%)$ the standard deviation of the outcome. Finally, given the low premiums for RSBY insurance, it would require a rather precise nearly zero estimate of health effects to rule out that government spending on freely provided insurance was not cost-effective.

\footnotetext{
${ }^{13}$ Such strategic behavior has been documented in other medical contexts: Alexander (2020) shows that doctors in the US strategically turn away patients who are unlikely to generate large billable fees.

${ }^{14}$ We find no robust evidence that the inability to successfully use insurance at 18 months led to significantly lower utilization at 3.5 years (unreported).
} 


\section{Conclusion}

Our study finds that access to insurance increased enrollment. Enrollment increased insurance payment for care, assisted by spillover effects from other village households given access to insurance. Many beneficiaries were unable to use their insurance card. Ultimately, the effect of enrollment on health was insignificant.

The insignificant health effects found here are consistent with prior experimental studies of health insurance in Mexico, Cambodia, Nicaragua and Kenya (King, Gakidou et al. 2009, Thornton, Hatt et al. 2010, Levine, Polimeni et al. 2016, Haushofer, Chemin et al. 2020). Those studies also found small effects on healthcare utilization, which could explain minor health effects. (However, not accounting for spillovers may explain null effects on insurance utilization in studies that do not provide insurance to large portions of a village (Haushofer, Chemin et al. 2017).) Our insignificant findings are consistent with studies that show that healthcare quality in developing countries is low (Kruk, Gage et al. 2018).

This study is, to our knowledge, the largest experimental evaluation of health insurance in an emerging economy and the first to examine spillover effects. Nevertheless, it has limitations. First, the study was designed to be powered to detect a change in the hospitalization rate, not necessarily changes in health outcomes. Recent research has shown that samples sized in the millions may be required to find effects on rare outcomes, even with insurance that covers not just hospital care, as in this study, but also outpatient care and drugs (Goldin, Lurie et al. 2019). Second, the study examines a plan without coverage for non-surgical outpatient care and prescription drugs. This limits applicability to more comprehensive insurance schemes. Third, while the study helps predict the effect of expanding eligibility under India's new PMJAY insurance, it does not inform the effects of that plan's expansion of coverage to non-acute hospital treatments.

Our findings have implications for the implementation of public insurance in India. First, many households were unable to use their insurance. This finding is consistent with a prior study of Seguro Popular in Mexico (King, Gakidou et al. 2009). It is also consistent with results from Banerjee, Finkelstein et al. (2021), which finds that Indonesians had difficulty enrolling in a public health insurance scheme. In our context, the reasons given suggested that respondents did not understand what coverage was provided or forgot their insurance card, or that hospitals did not accept RSBY coverage. This may be due to unfamiliarity with insurance (Rajasekhar, Berg et al. 2011, Nandi, Dasgupta et al. 2016), low reimbursement rates that discouraged hospitals from accepting RSBY (Devadasan, Seshadri et al. 2013), or a failure of RSBY's payment infrastructure. Improved educational materials, higher reimbursement rates, and increased investment in IT should be considered. These reforms may affect long-term success: the inability to use RSBY early in the study may explain why insurance use was low after 3.5 years (Fenton, Jerant et al. 2012, Trivedi and Saxena 2013). 
Second, spillover effects on utilization have implications for marketing insurance. With a fixed budget, the government may achieve greater utilization by focusing on increasing coverage within a smaller number of villages rather than spreading resources over more villages with lower coverage in each. 


\section{Tables and Figures}

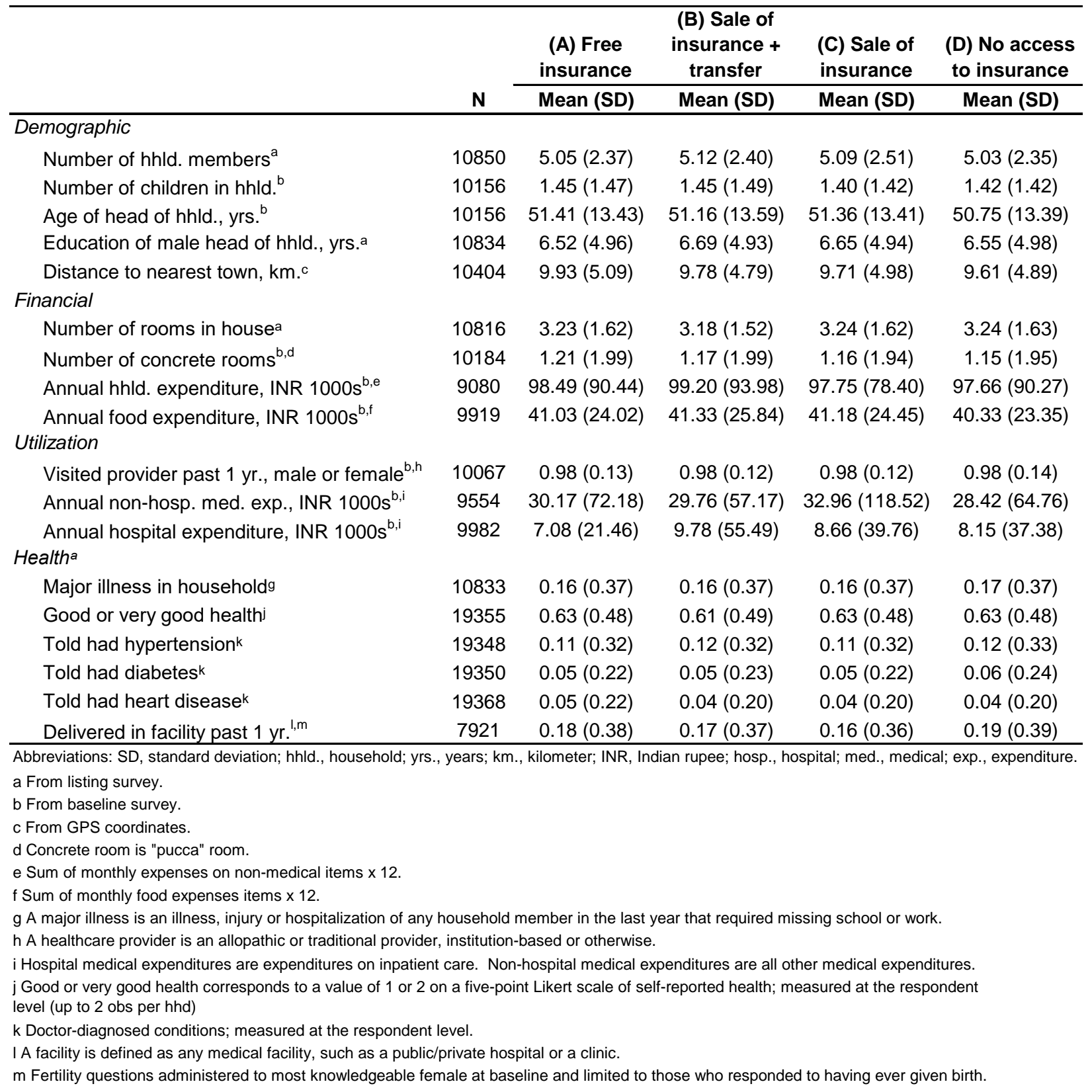


Table 2. Direct and indirect effects of insurance access on insurance enrollment. ${ }^{a}$

\begin{tabular}{lccc} 
& Direct effects & Spillover effects & Total effects \\
\cline { 2 - 4 } & Coefficient & Coefficient & $\begin{array}{c}\text { Coefficient } \\
\text { (95\% Cl) }\end{array}$ \\
& $\mathbf{( 9 5 \% ~ C l )}$ & $\mathbf{( 9 5 \% ~ C l )}$ & P-value \\
\hline (A) Free insurance & P-value & P-value & $78.71 \%$ \\
& $(63.02 \%$ to $81.82 \%)$ & $(-4.16 \%$ to $18.15 \%)$ & $(76.95 \%$ to $80.47 \%)$ \\
(B) Sale of insurance & 0.000 & 0.219 & 0.000 \\
$\quad+$ transfer & $65.19 \%$ & $7.83 \%$ & $72.24 \%$ \\
& $(49.79 \%$ to $80.60 \%)$ & $(-10.53 \%$ to $26.19 \%)$ & $(69.56 \%$ to $74.91 \%)$ \\
(C) Sale of insurance & 0.000 & 0.402 & 0.000 \\
& $48.40 \%$ & $12.79 \%$ & $59.91 \%$ \\
& $(32.52 \%$ to $64.28 \%)$ & $(-6.48 \%$ to $32.06 \%)$ & $(56.76 \%$ to $63.06 \%)$ \\
$\mathrm{N}$ & 0.000 & 0.193 & 0.000 \\
\hline
\end{tabular}

Abbreviations: $\mathrm{Cl}$, confidence interval.

a Each observation is a household. Treatment variables are household assignments: free insurance (A), sale of insurance + cash transfer $(B)$, sale of insurance $(C)$. Estimates are intent-to-treat effects; all models estimated with OLS. Each treatment arm was interacted with the share of the village allocated to A, B, or C (combined). Standard errors were clustered at the village level. Coefficients were transformed to show percentage point changes from the control group D. Enrollment rate is 0 in the control group D. The direct effect only includes the coefficient on treatment $A, B$, or $C$. The spillover effect is the estimated effect on a treated household of assigning all other sample households in the village to the same treatment. The total effect is constructed as the sum of the direct effect and $0.9^{*}$ (spillover effect). 
Table 3. Effect of insurance access on use of insurance for hospital care and on hospital utilization (ITT). ${ }^{a}$

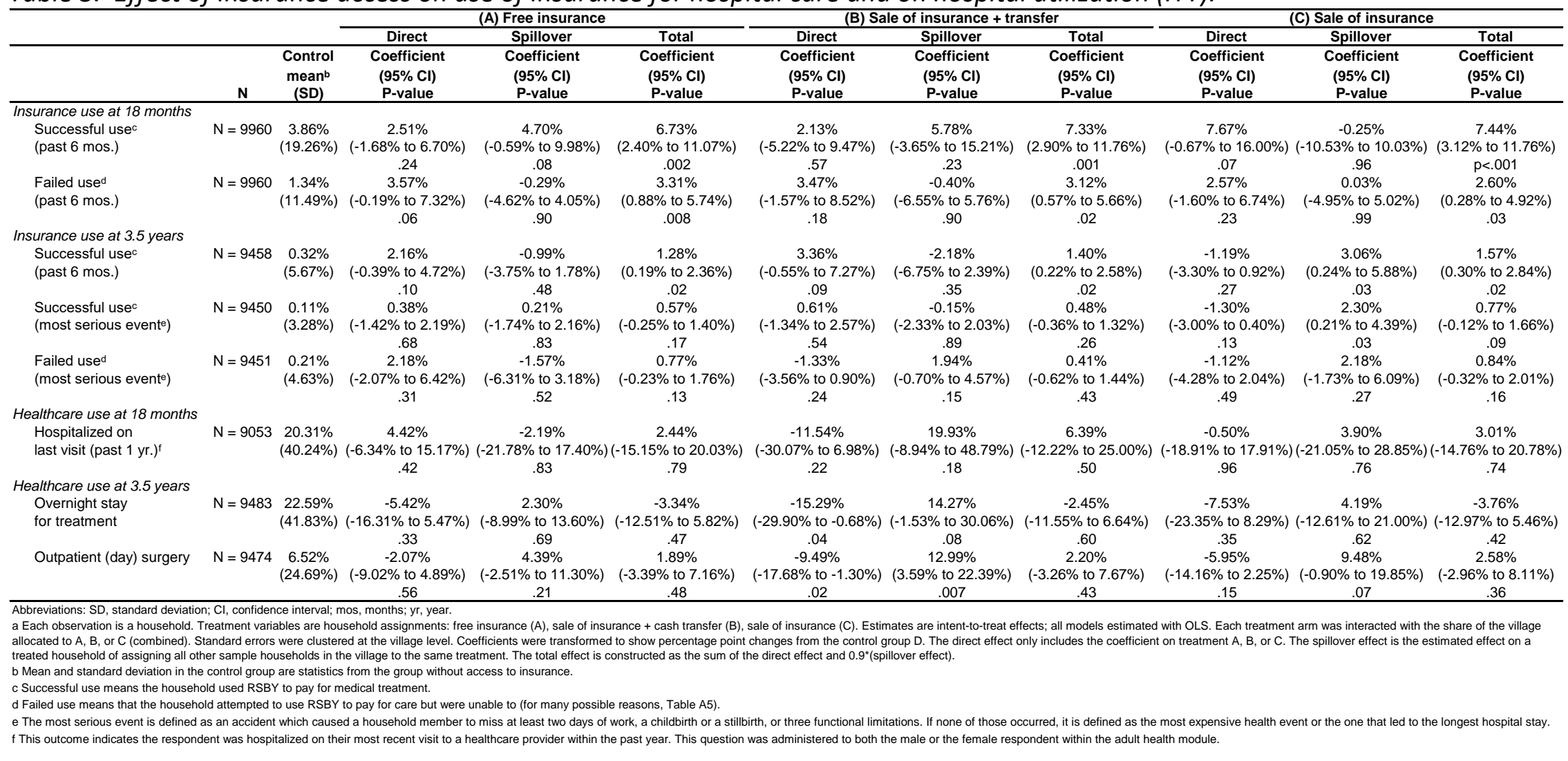


Table 4. Direct and indirect effects of insurance enrollment on use of insurance and visits to medical facilities (TOT). ${ }^{a}$

\begin{tabular}{|c|c|c|c|c|c|}
\hline & $\mathbf{N}$ & $\begin{array}{l}\text { Control } \\
\text { mean }^{b} \\
\text { (SD) }\end{array}$ & $\begin{array}{c}\text { Direct effectc } \\
\text { Coefficient } \\
(95 \% \mathrm{Cl}) \\
\text { P-value } \\
\end{array}$ & $\begin{array}{c}\text { Spillover effect }^{\mathrm{d}} \\
\text { Coefficient } \\
(95 \% \mathrm{Cl}) \\
\text { P-value } \\
\end{array}$ & $\begin{array}{c}\text { Total effecte } \\
\text { Coefficient } \\
\text { (95\% Cl) } \\
\text { P-value } \\
\end{array}$ \\
\hline \multicolumn{6}{|l|}{ Insurance use at 18 months } \\
\hline $\begin{array}{l}\text { Successful use } \\
\text { (past } 6 \text { mos.) }\end{array}$ & $N=9960$ & $\begin{array}{c}3.88 \% \\
(19.32 \%)\end{array}$ & $\begin{array}{c}3.89 \% \\
(-1.43 \% \text { to } 9.21 \%) \\
.15\end{array}$ & $\begin{array}{c}2.70 \% \\
(-6.03 \% \text { to } 11.43 \%) \\
.54\end{array}$ & $\begin{array}{c}6.02 \% \\
\text { (1.13\% to } 10.91 \%) \\
.02\end{array}$ \\
\hline $\begin{array}{l}\text { Failed useg } \\
\text { (past } 6 \text { mos.) }\end{array}$ & $N=9960$ & $\begin{array}{c}1.50 \% \\
(12.15 \%)\end{array}$ & $\begin{array}{c}3.59 \% \\
(-0.07 \% \text { to } 7.26 \%) \\
.05\end{array}$ & $\begin{array}{c}-0.11 \% \\
(-5.34 \% \text { to } 5.12 \%) \\
.97\end{array}$ & $\begin{array}{c}3.51 \% \\
(0.98 \% \text { to } 6.03 \%) \\
.006\end{array}$ \\
\hline \multicolumn{6}{|l|}{ Insurance use at 3.5 years } \\
\hline $\begin{array}{l}\text { Successful usef } \\
\text { (past } 6 \text { mos.) }\end{array}$ & $N=9458$ & $\begin{array}{c}0.49 \% \\
(6.99 \%)\end{array}$ & $\begin{array}{c}2.73 \% \\
(0.45 \% \text { to } 5.01 \%) \\
.02\end{array}$ & $\begin{array}{c}-1.54 \% \\
(-4.67 \% \text { to } 1.59 \%) \\
.34\end{array}$ & $\begin{array}{c}1.52 \% \\
(0.37 \% \text { to } 2.67 \%) \\
.009\end{array}$ \\
\hline $\begin{array}{l}\text { Successful use }{ }^{f} \\
\left(\text { most serious event }{ }^{h}\right)\end{array}$ & $N=9450$ & $\begin{array}{c}0.13 \% \\
(3.59 \%)\end{array}$ & $\begin{array}{c}0.46 \% \\
(-1.13 \% \text { to } 2.05 \%) \\
.57\end{array}$ & $\begin{array}{c}0.66 \% \\
(-1.40 \% \text { to } 2.72 \%) \\
.53\end{array}$ & $\begin{array}{c}0.98 \% \\
(0.23 \% \text { to } 1.73 \%) \\
.01\end{array}$ \\
\hline $\begin{array}{l}\text { Failed use } \\
\left(\text { most serious eventh }{ }^{h}\right)\end{array}$ & $N=9451$ & $\begin{array}{c}0.57 \% \\
(7.52 \%)\end{array}$ & $\begin{array}{c}1.23 \% \\
(-1.99 \% \text { to } 4.44 \%) \\
.46\end{array}$ & $\begin{array}{c}0.32 \% \\
(-4.17 \% \text { to } 4.81 \%) \\
.89\end{array}$ & $\begin{array}{c}1.48 \% \\
(0.38 \% \text { to } 2.57 \%) \\
.008\end{array}$ \\
\hline \multicolumn{6}{|l|}{ Healthcare use at 18 months } \\
\hline $\begin{array}{l}\text { Hospitalized on } \\
\text { last visit (past } 1 \text { yr.) }^{\mathrm{i}}\end{array}$ & $N=9053$ & $\begin{array}{c}20.82 \% \\
(40.61 \%)\end{array}$ & $\begin{array}{c}0.83 \% \\
(-11.65 \% \text { to } 13.30 \%)\end{array}$ & $\begin{array}{c}6.00 \% \\
(-18.46 \% \text { to } 30.45 \%)\end{array}$ & $\begin{array}{c}5.55 \% \\
(-12.03 \% \text { to } 23.12 \%\end{array}$ \\
\hline & & & .90 & .63 & .54 \\
\hline \multicolumn{6}{|l|}{ Healthcare use at 3.5 years } \\
\hline $\begin{array}{l}\text { Overnight stay } \\
\text { for treatment }\end{array}$ & $N=9483$ & $\begin{array}{c}22.97 \% \\
(42.07 \%)\end{array}$ & $\begin{array}{c}-12.44 \% \\
(-24.26 \% \text { to }-0.62 \%) \\
.04\end{array}$ & $\begin{array}{c}14.64 \% \\
(0.17 \% \text { to } 29.12 \%) \\
.05\end{array}$ & $\begin{array}{c}-0.92 \% \\
(-9.07 \% \text { to } 7.24 \%) \\
.83\end{array}$ \\
\hline Outpatient (day) surgery & $N=9474$ & $\begin{array}{c}6.76 \% \\
(25.11 \%)\end{array}$ & $\begin{array}{c}-4.15 \% \\
(-10.98 \% \text { to } 2.69 \%) \\
.23\end{array}$ & $\begin{array}{c}10.46 \% \\
(1.92 \% \text { to } 19.00 \%) \\
.02\end{array}$ & $\begin{array}{c}4.09 \% \\
(-0.94 \% \text { to } 9.11 \%) \\
.11\end{array}$ \\
\hline
\end{tabular}

a Each observation is a household. Treatment variable is enrollment. Estimates are complier average treatment effects. Observations are weighted so each household has equal weight. Standard errors were clustered at the village level. Coefficients were transformed to show percentage point changes from the control group.

b Mean and standard deviation in the control group are statistics from the unenrolled group.

c The direct effect is the estimated effect of enrolling one household, assuming no other sample households in the village are enrolled.

d The spillover effect is the estimated effect on an enrolled household of enrolling all other sample households in the village.

e Total effects are the sum of direct and (spillover effects) ${ }^{*}$ (uptake into free insurance). The total effect of free insurance on uptake is estimated as 0.7871 in Table 2.

f Successful use means the household used RSBY to pay for medical treatment.

$\mathrm{g}$ Failed use means that the household attempted to use RSBY to pay for care but were unable to (for many possible reasons, eTable 6).

$\mathrm{h}$ The most serious event is defined as an accident which caused a household member to miss at least two days of work, a childbirth or a stillbirth, or three functional limitations. If none of those occurred, it is defined as the most expensive health event or the one that led to the longest hospital $i$ This outcome indicates the respondent was hospitalized on their most recent visit to a healthcare provider within the past year. This question was
administered to both the male or the female respondent 
Table 5. Number of significant health outcomes per category. ${ }^{a}$

\begin{tabular}{|c|c|c|c|c|c|c|c|c|c|}
\hline & & & & & & & & & \\
\hline \multirow[b]{3}{*}{ Health category } & & \multicolumn{4}{|c|}{18 months (Midline) } & \multicolumn{4}{|c|}{3.5 years (Endline) } \\
\hline & & \multicolumn{3}{|c|}{ C } & \multirow{2}{*}{$\begin{array}{c}\text { TOT } \\
\\
\text { Enrollment }\end{array}$} & \multicolumn{3}{|c|}{ (1) } & \multirow[b]{2}{*}{ Enrollment } \\
\hline & & $\begin{array}{c}\text { (A) Free } \\
\text { insurance }\end{array}$ & $\begin{array}{l}\text { (B) Sale of } \\
\text { insurance } \\
+ \text { transfer }\end{array}$ & $\begin{array}{l}\text { (C) Sale of } \\
\text { insurance }\end{array}$ & & $\begin{array}{c}\text { (A) Free } \\
\text { insurance }\end{array}$ & $\begin{array}{l}\text { (B) Sale of } \\
\text { insurance } \\
+ \text { transfer }\end{array}$ & $\begin{array}{l}\text { (C) Sale of } \\
\text { insurance }\end{array}$ & \\
\hline \multirow[t]{4}{*}{ Self-reported health } & Total outcomes & 1 & 1 & 1 & 1 & 2 & 2 & 2 & 2 \\
\hline & Significant direct effect & 0 & 0 & 0 & 0 & 0 & 0 & 0 & 0 \\
\hline & Significant spillover effect & 0 & 0 & 0 & 0 & 0 & 0 & 0 & 0 \\
\hline & Significant total & 0 & 0 & 0 & 0 & 0 & 0 & 0 & 0 \\
\hline \multirow[t]{4}{*}{ Chronic disease } & Total outcomes & 15 & 15 & 15 & 15 & 17 & 17 & 17 & 17 \\
\hline & Significant direct effect & 0 & 0 & 1 & 0 & 0 & 0 & 0 & 0 \\
\hline & Significant spillover effect & 0 & 0 & 0 & 0 & 0 & 0 & 0 & 0 \\
\hline & Significant total & 0 & 0 & 0 & 0 & 0 & 0 & 0 & 0 \\
\hline \multirow[t]{4}{*}{ Quality of life } & Total outcomes & 1 & 1 & 1 & 1 & 14 & 14 & 14 & 14 \\
\hline & Significant direct effect & 0 & 0 & 0 & 0 & 0 & 0 & 0 & 0 \\
\hline & Significant spillover effect & 0 & 0 & 0 & 0 & 0 & 0 & 0 & 0 \\
\hline & Significant total & 0 & 0 & 0 & 0 & 0 & 1 & 0 & 0 \\
\hline \multirow{4}{*}{$\begin{array}{l}\text { Mental and behavioral } \\
\text { health }\end{array}$} & Total outcomes & 0 & 0 & 0 & 0 & 3 & 3 & 3 & 3 \\
\hline & Significant direct effect & & & & & 0 & 0 & 0 & 0 \\
\hline & Significant spillover effect & & & & & 0 & 0 & 0 & 0 \\
\hline & Significant total & & & & & 0 & 0 & 0 & 0 \\
\hline \multirow[t]{4}{*}{ Childbirth } & Total outcomes & 8 & 8 & 8 & 8 & 10 & 10 & 10 & 10 \\
\hline & Significant direct effect & 0 & 0 & 0 & 0 & 0 & 0 & 0 & 0 \\
\hline & Significant spillover effect & 0 & 0 & 0 & 0 & 0 & 0 & 0 & 0 \\
\hline & Significant total & 0 & 0 & 0 & 0 & 0 & 0 & 0 & 0 \\
\hline \multirow[t]{4}{*}{ Biomarkers } & Total outcomes & 7 & 7 & 7 & 7 & 0 & 0 & 0 & 0 \\
\hline & Significant direct effect & 0 & 0 & 0 & 1 & & & & \\
\hline & Significant spillover effect & 0 & 0 & 0 & 0 & & & & \\
\hline & Significant total & 0 & 0 & 0 & 0 & & & & \\
\hline \multirow[t]{4}{*}{ Mortality } & Total outcomes & 0 & 0 & 0 & 0 & 4 & 4 & 4 & 4 \\
\hline & Significant direct effect & & & & & 0 & 0 & 0 & 0 \\
\hline & Significant spillover effect & & & & & 0 & 0 & 0 & 0 \\
\hline & Significant total & & & & & 0 & 0 & 0 & 0 \\
\hline
\end{tabular}

Each treatment arm was interachold assignments: free insurance (A), sale of insurance + cash transfer (B), sale of insurance (C). Estimates are intent-to-treat effects; all models estimated with OLS. wise error rate (FWER) critical p-value at the $5 \%$ significance level. 


\section{Appendix}

\section{Methods}

\section{A. Participants}

The sampling strategy, implemented in 2013, first identified eligible villages and then eligible households within villages. Villages were included if they met 2 criteria:

1. Were in Gulbarga or Mysore district, Karnataka State, and

2. Were within 15.63 miles $(25 \mathrm{~km}$ ) of a hospital that is in-network in Rashtriya Swasthya Bima Yojana (RSBY) in 2013.

Within eligible villages, households were included if they answered the door and met 1 inclusion criteria:

1. Had a member that held an Above Poverty Line (APL) ration card.

Households were excluded if, as of 2013, they

1. Had a member who possessed a card indicating they were below-the-poverty-line (BPL);

2. Had RSBY coverage; or

3. Had a member that was enrolled in insurance that provided access to secondary hospital care.

The sample was identified via a listing exercise and a consent process. The listing was conducted in two waves, in March-June 2013 and in November-December 2013. The actual randomized sample was smaller than the listing because not all listed households were available the days we approached households for consent and because many households became ineligible by the time they were approached for consent. The main cause of ineligibility is that households obtained BPL cards. A total of 8,866 and 2,013 households were identified and enrolled from the two listing waves, respectively. Figure A1 presents the Recruitment randomization and follow-up flowchart for both districts combined.

\section{B. Randomization}

In order to generate variation in both types of access to insurance (household-level conditions) and in the share of a village given access to insurance (village-level conditions), a 2 stage randomization process was employed separately in each district (Gulbarga, Mysore).

The first-stage randomization in each district varied the share of sample households in a village allocated to different household-level groups. The probabilities of assignment to and descriptions of each village condition are given in Figure A2. Matching before randomization 
increases the power to detect spillovers because it reduces orthogonal variation (Imai, King et al. 2009). Therefore, the first stage was implemented in 2 steps. First, blocks of 20 matched villages were created. Specifically, villages were stratified into quintiles based on the number of eligible households per village. Within each quintile, blocks were constructed using village-level sample averages, Mahalanobis matching on continuous and integer variables (head of household's level of education, age of head of household, number of children and number of rooms in the house), and caliper matching on binary variables (had major illness in last year and head of household was unemployed). These variables were constructed from a listing exercise to determine eligible villages in each village of our sample prior to our baseline survey. Second, within each block, villages were randomly assigned to 5 village-level conditions without replacement.

The second stage of randomization assigned households in a village to household-level groups based on the village-level group to which the village was assigned. This stage also had 2 steps. First, households were sorted into blocks of 10 matched households. These blocks were constructed using household-level data gathered during our listing exercise and Mahalanobis matching on the same continuous variables and caliper matching on the same binary variables used for constructing village blocks. Second, within each block, households were randomly assigned to 4 household conditions based on the village condition to which we assigned their village in stage one.

We conducted balancing tests to investigate the validity of our randomization. First, we estimated multinomial-logit models predicting household group assignment to the 4 treatment groups as a function of outcomes specified in our pre-analysis plan and measured at baseline, one outcome at a time. Second, we conducted likelihood-ratio tests to determine if we can reject a null model equal to the multinomial model without any baseline outcome, i.e., reject that the baseline outcome has no explanatory power. If the randomization was successful, then the $p$-values collected from these tests should stochastically dominate the uniform distribution. A one-sided Kolmogorov-Smirnov test reveals that outcomes are balanced $(P=1.000)$ across insurance-access arms (Figure A4).

\section{Intervention}

Enrollment took place just after the government conducted its enrollment drive in early 2015. We used the same enrollment method (mobile enrollment vans) the government used. There were two differences in the marketing of RSBY. First, households were visited roughly 14 days prior to arrival of the enrollment van to inform them of their treatment condition and if appropriate give them a cash transfer. Second, we visited households eligible to enroll the day the van arrived to guide them to the van. By contrast, the government conducted its enrollment drive by circulating flyers (chits) to eligible households a few days before the van. The government did not guide eligible households to the enrollment van. For all sample 
households that enrolled in RSBY, we collected the full amount (insurance premium plus cost of insurance card) to be paid by households and paid this amount to the government.

The Karnataka government automatically renewed RSBY coverage annually for nonstudy and study households in 2016 and 2017 without any action-even payment-by enrollees. RSBY technically ended on August 31, 2018, because it was superseded by Pradhan Mantri Jal Arogya Yojana (PMJAY), a part of Ayushman Bharat Yojana. As of completion of data gathering, Karnataka had agreed to implement PMJAY but had not yet rolled it out.

\section{Outcomes}

We employ a series of health scores as outcomes. Good or very good health is an indicator for a score of 1 or 2 on a 5-point Likert scale for self-reported health. SF-8 physical and mental health component scores are from a two-factor factor analysis of the Short Form 8item survey (Lang, Zhang et al. 2018). PSS-10 is the sum of answers to the 10-item Perceived Stress survey (Cohen, Kessler et al. 1997). GHQ-12 scores symptomatic responses to the General Health Questionnaire as 1 and sums them.

\section{E. Data collection}

In March-June 2013 and again in November-December 2013, we conducted listing exercises wherein we surveyed 1 adult in 25,000 households in candidate villages to identify eligible households and gather data to construct blocks of similar villages and households prior to randomization.

In August 2013-January 2014, a baseline survey was administered to the female and male most knowledgeable about household finances and a female of childbearing age in each sample household we could reach. The biomarker survey conducted as part of the baseline was administered to the male most knowledgeable, a woman of childbearing age, and a child under the age of 18 if available in roughly, a randomly-selected one-third of sample households. This subsample was selected in two steps. First, we stratified households by the two districts in our study. Second, we selected one third of villages in each district and conducted the biomarker survey on each sample household in the selected villages. A discrepancy between one-third of households and the number on which the biomarker survey was attempted reflected both the fact that we selected one-third of villages not households and villages have different sample sizes. The actual number of households ultimately surveyed - for both the main and biomarker survey - was less than the number attempted because of non-response. Households were paid $₹ 250$ (\$14.27) as a participation incentive for completing major sections of the survey. We performed back checks on $10 \%$ of households, a rate known to surveyors ex ante.

In January-May 2017, a midline survey was administered in the same manner as the baseline survey, including the biomarker survey on the same randomly-selected sample 
households. Households were paid the same participation incentives and back checks were performed in the same manner.

In March-June 2019, we conducted an endline survey of all sample households to measure outcomes after approximately 3.5 years. We asked the female most knowledgeable about household finances from baseline a subset of questions about personal health status and household health care utilization and finances. No biomarker survey was conducted at endline. We paid households ₹50 (\$2.85) as a participation incentive since only 1 individual was surveyed and for a shorter period. We performed back checks on $10 \%$ of households, a rate known to surveyors ex ante.

Figure A3 presents the study timeline, both in terms of the intervention and the multiple surveys conducted.

\section{F. Economic calculations}

We convert Indian Rupees (₹) to 2019 US Dollars using a purchasing power parity adjusted exchange rate of ₹17.52/dollar (OECD 2020).

We calculated the demand elasticity for hospital insurance with the following formula:

[(Enrollment in Group A - Enrollment in Group C)/(Enrollment in C)] $\div$ [(Price for insurance in $C$ - Price in $A) /($ Premium in $C)$ ]

The price for $C$ is ₹173 (\$9.87), including the cost of the insurance card. We do not use the usual arc elasticity formula, which normalizes by the midpoint of enrollment and price, because our change in price is going from full price to zero price. Our formula implies this is a $100 \%$ reduction in price while the usual arc elasticity formula would imply this is a nonsensical $200 \%$ reduction in price. 
Figures 
Figure A1. Patient flowchart.

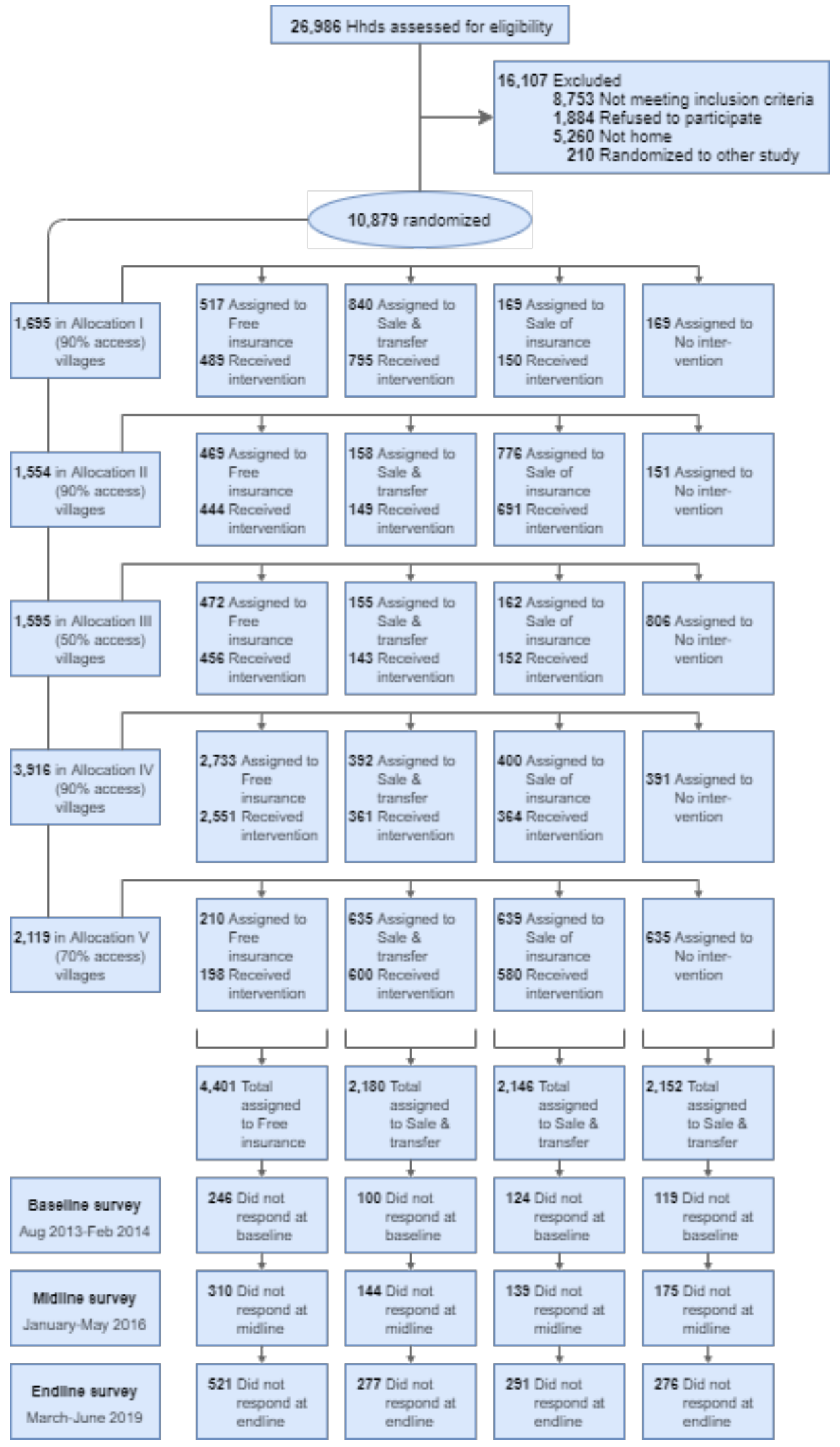


Figure A2. Flowchart illustrating trial design in each district, including assignment of villages to allocation conditions and of households to insurance access conditions.

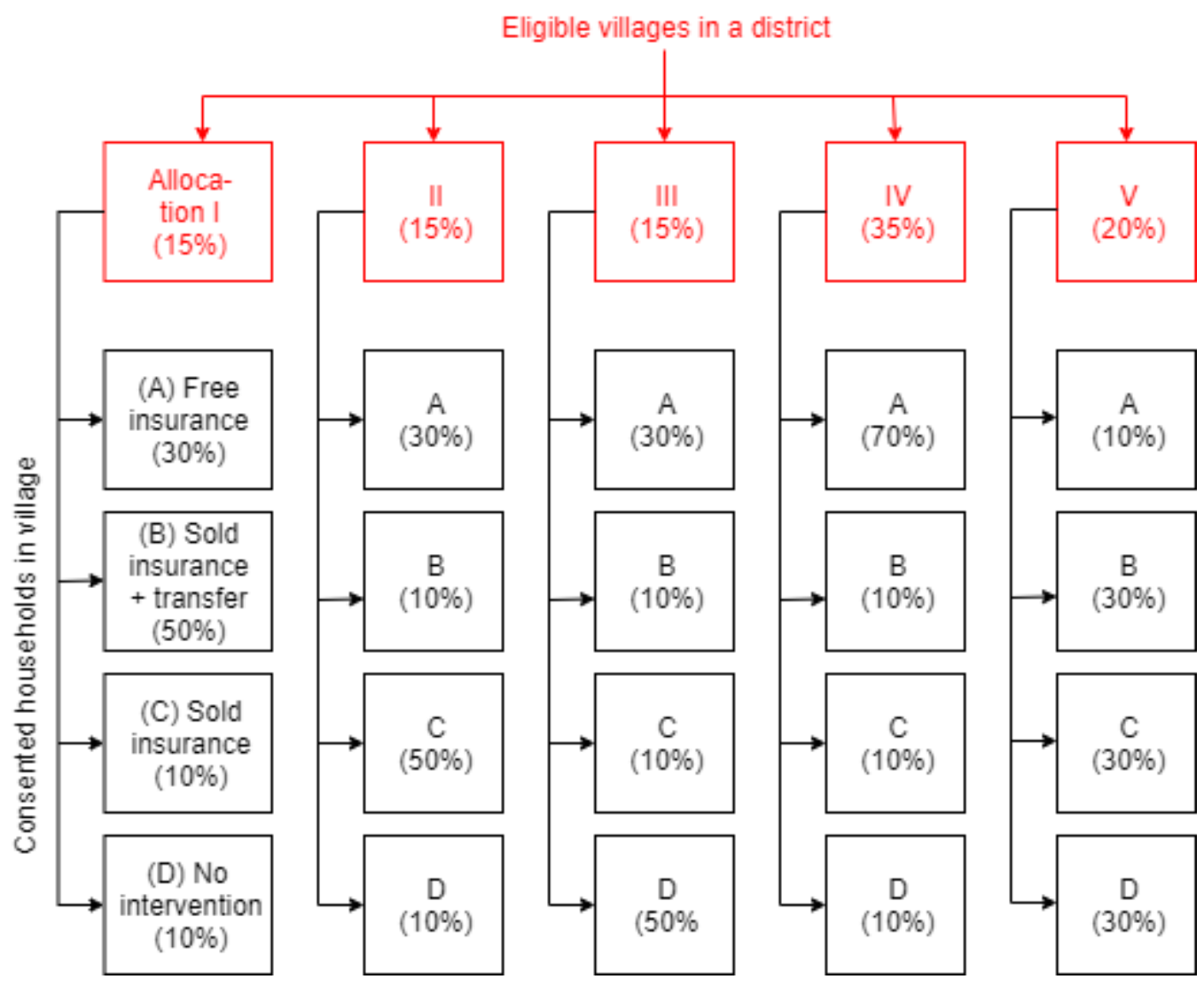

Figure A3. Timeline of study.

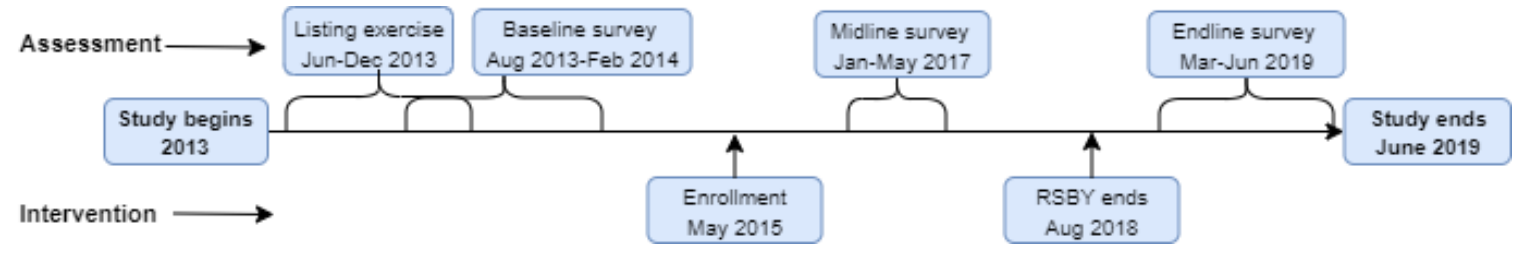


Figure A4. Cumulative distribution of $p$-values from likelihood ratio tests checking balance in outcomes across arms and from a uniform distribution (capturing perfect randomization).

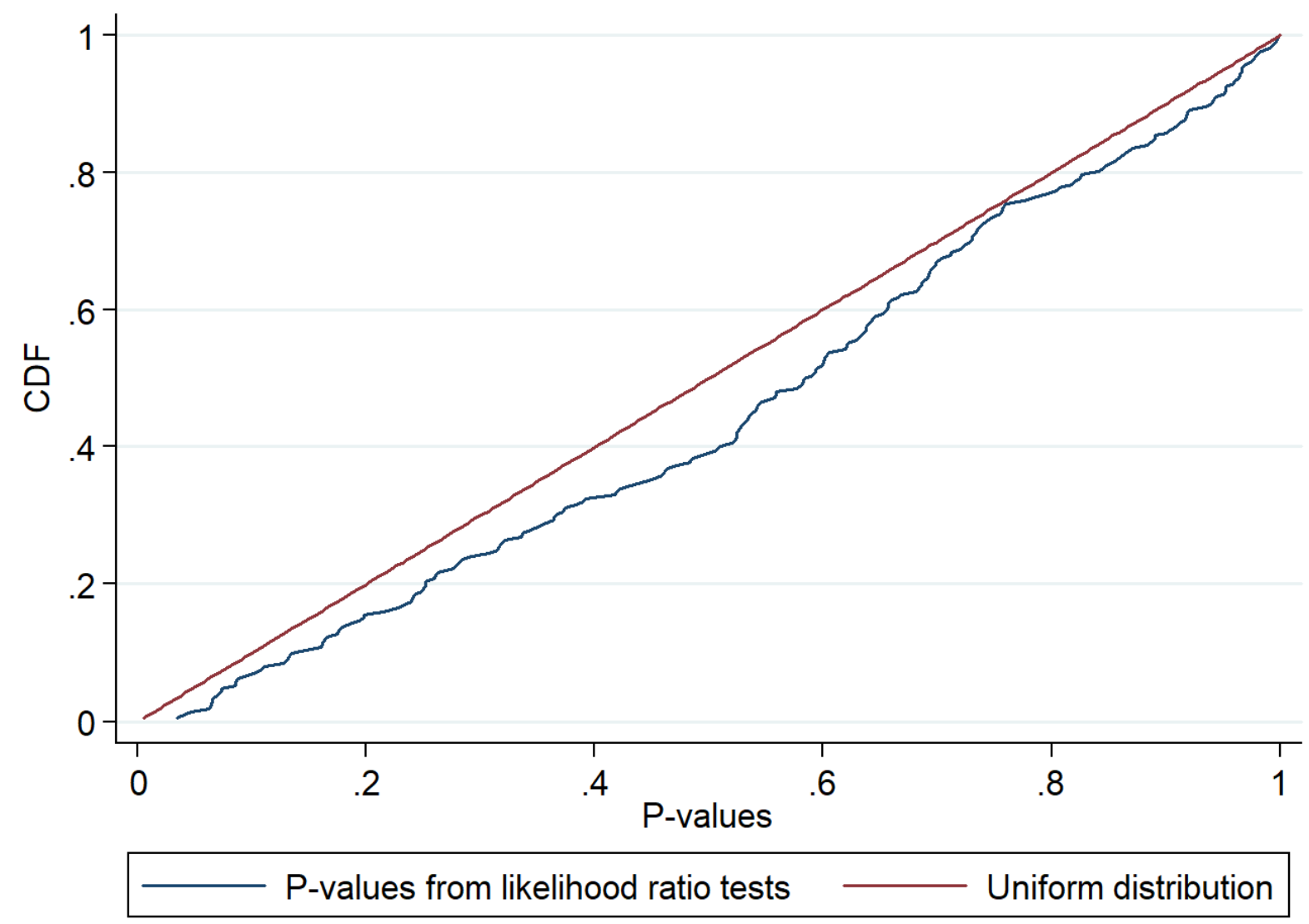


Tables 
Table A1. Outcomes measured by topic at midline (18 months post-intervention) and endline (3.5 years post-intervention) surveys.

\begin{tabular}{|c|c|c|}
\hline & $\begin{array}{l}18 \text { months } \\
\text { (Midline) }\end{array}$ & $\begin{array}{l}3.5 \text { years } \\
\text { (Endline) }\end{array}$ \\
\hline \multicolumn{3}{|l|}{ Utilization } \\
\hline Inpatient or overnight hospital stay & $\mathrm{x}$ & $\mathrm{x}$ \\
\hline Successful RSBY use for treatment & $x$ & $x$ \\
\hline \multicolumn{3}{|l|}{ Other utilization metrics } \\
\hline Outpatient (day) surgery & & $x$ \\
\hline Failed RSBY use for treatment & $\mathrm{x}$ & $\mathrm{x}$ \\
\hline \multicolumn{3}{|l|}{ Health value } \\
\hline Sickness & & $\mathrm{x}$ \\
\hline Good or very good health & $x$ & $x$ \\
\hline Very good health & $x$ & $x$ \\
\hline Poor or very poor health & $x$ & $x$ \\
\hline Very poor health & $x$ & $x$ \\
\hline \multicolumn{3}{|l|}{ Chronic disease } \\
\hline Told had hypertension & $\mathrm{x}$ & $\mathrm{x}$ \\
\hline Takes medication for hypertension & $x$ & $x$ \\
\hline Told had diabetes & $x$ & $x$ \\
\hline Takes oral medication for diabetes & $x$ & $x$ \\
\hline Takes insulin for diabetes & $x$ & $x$ \\
\hline Follows a special diet for diabetes & $x$ & $x$ \\
\hline Told had cancer & $x$ & $x$ \\
\hline Treated for cancer past $1 \mathrm{yr}$. & $x$ & $x$ \\
\hline Told had lung disease & $x$ & $x$ \\
\hline Told had heart disease & $x$ & $x$ \\
\hline Told had stroke & $x$ & $x$ \\
\hline Told had arthritis or rheumatism & $x$ & $x$ \\
\hline Had surgery due to arthritis past $1 \mathrm{yr}$. & $x$ & $x$ \\
\hline Diagnosed with high cholesterol & $x$ & $\mathrm{x}$ \\
\hline Takes medication to lower cholesterol & $x$ & $x$ \\
\hline Has eyesight problems & & $x$ \\
\hline Had surgery due to eye problems past $1 \mathrm{yr}$. & & $x$ \\
\hline \multicolumn{3}{|l|}{ Quality of life } \\
\hline Number of functional limitations & & $x$ \\
\hline SF-8, PCS & & $x$ \\
\hline SF-8, MCS & & $x$ \\
\hline Had stomach pain past 4 wks. & & $x$ \\
\hline Had back pain past 4 wks. & & $x$ \\
\hline Had chest pain past 4 wks. & $x$ & $x$ \\
\hline Had joint pain past 4 wks. & & $x$ \\
\hline Had headaches past 4 wks. & & $x$ \\
\hline Had menstrual cramps past 4 wks. & & $x$ \\
\hline Had pain in no specific place past 4 wks. & & $x$ \\
\hline Fainted past 4 wks. & & $x$ \\
\hline Felt dizzy past 4 wks. & & $x$ \\
\hline Shortness of breath past 4 wks. & & $\mathrm{x}$ \\
\hline Heart pounded past 4 wks. & & $\mathrm{x}$ \\
\hline
\end{tabular}


Table A1 (continued). Outcomes measured by topic at midline (18 months post-intervention) and endline (3.5 years post-intervention) surveys.

\begin{tabular}{|c|c|c|}
\hline & $\begin{array}{l}18 \text { months } \\
\text { (Midline) }\end{array}$ & $\begin{array}{l}3.5 \text { years } \\
\text { (Endline) }\end{array}$ \\
\hline \multicolumn{3}{|l|}{ Mental and emotional health } \\
\hline GHQ-12, Likert scoring & & $\mathrm{x}$ \\
\hline GHQ-12, binary scoring & & $\mathrm{x}$ \\
\hline PSS-10 score & & $\mathrm{x}$ \\
\hline \multicolumn{3}{|l|}{ Childbirth } \\
\hline Childbirth/stillbirth past 6 mos. & $\mathrm{x}$ & $\mathrm{x}$ \\
\hline Childbirth/stillbirth past 3 yrs. & $x$ & $x$ \\
\hline Number of births in hhld. past 3 yrs. & & $\mathrm{x}$ \\
\hline Number of live births in hhld. past 3 yrs. & & $\mathrm{x}$ \\
\hline Number of still births in hhld. past 3 yrs. & & $x$ \\
\hline Delivery in hospital past 3 yrs. & $\mathrm{x}$ & $x$ \\
\hline Delivery in facility past 3 yrs. & $x$ & $x$ \\
\hline Doctor assisted with birth past 3 yrs. & $x$ & $x$ \\
\hline Doctor or nurse assisted with birth past 3 yrs. & $x$ & $\mathrm{x}$ \\
\hline Delivery complications past 3 yrs. & $x$ & $\mathrm{x}$ \\
\hline Ideal number of children & $\mathrm{x}$ & \\
\hline \multicolumn{3}{|l|}{ Biomarkers } \\
\hline Overweight or obese & $\mathrm{x}$ & \\
\hline Underweight & $x$ & \\
\hline Abdominally obese & $x$ & \\
\hline Mid-upper arm circumference & $x$ & \\
\hline Hypertension, grade 1 & $x$ & \\
\hline Hypertension, grade 2 & $x$ & \\
\hline Skinfolds total & $\mathrm{x}$ & \\
\hline \multicolumn{3}{|l|}{ Mortality } \\
\hline Death in hhld. past 3 yrs. & & $\mathrm{x}$ \\
\hline Number of deaths in hhld. & & $x$ \\
\hline Sickness-related death in hhld. past 3 yrs. & & $x$ \\
\hline Number of sickness-related deaths in hhld. & & $\mathrm{x}$ \\
\hline
\end{tabular}




\begin{tabular}{|c|c|c|c|c|c|c|c|}
\hline & \multicolumn{4}{|c|}{ Insurance access group } & \multirow[b]{2}{*}{ Totalb } & \multirow[b]{2}{*}{$\begin{array}{c}\text { Non- } \\
\text { responsec }\end{array}$} & \multirow[b]{2}{*}{ Attrition } \\
\hline & $\begin{array}{c}\text { (A) Free } \\
\text { insurance }\end{array}$ & $\begin{array}{c}\text { (B) Sale of } \\
\text { insurance + } \\
\text { transfer }\end{array}$ & $\begin{array}{l}\text { (C) Sale of } \\
\text { insurance }\end{array}$ & $\begin{array}{l}\text { (D) No access } \\
\text { to insurance }\end{array}$ & & & \\
\hline Sample for main surveys & 4,401 & 2,180 & 2,146 & 2,152 & 10,879 & & \\
\hline Sample for biomarker surveys & 1,363 & 718 & 737 & 833 & 3,651 & & \\
\hline \multicolumn{8}{|l|}{ Baseline survey } \\
\hline Main survey & $\begin{array}{l}4,155 \\
(94 \%)\end{array}$ & $\begin{array}{l}2,080 \\
(95 \%)\end{array}$ & $\begin{array}{l}2,022 \\
(94 \%)\end{array}$ & $\begin{array}{l}2,033 \\
(94 \%)\end{array}$ & $\begin{array}{c}10,290 \\
(95 \%)\end{array}$ & $\begin{array}{c}558 \\
(5 \%)\end{array}$ & $\begin{array}{c}31 \\
(0.2 \%)\end{array}$ \\
\hline Biomarker survey & $\begin{array}{c}1145 \\
(84 \%)\end{array}$ & $\begin{array}{c}588 \\
(82 \%)\end{array}$ & $\begin{array}{c}615 \\
(83 \%)\end{array}$ & $\begin{array}{c}692 \\
(83 \%)\end{array}$ & $\begin{array}{c}3040 \\
(83 \%)\end{array}$ & $\begin{array}{c}611 \\
(17 \%)\end{array}$ & \\
\hline \multicolumn{8}{|l|}{ Midline (18 mos.) follow-up } \\
\hline Main survey & $\begin{array}{l}4,091 \\
(93 \%)\end{array}$ & $\begin{array}{l}2,036 \\
(93 \%)\end{array}$ & $\begin{array}{l}2,007 \\
(94 \%)\end{array}$ & $\begin{array}{l}1,977 \\
(92 \%)\end{array}$ & $\begin{array}{c}10,111 \\
(93 \%)\end{array}$ & $\begin{array}{c}439 \\
(4 \%)\end{array}$ & $\begin{array}{c}329 \\
(3 \%)\end{array}$ \\
\hline Biomarker survey & $\begin{array}{c}1043 \\
(77 \%)\end{array}$ & $\begin{array}{c}546 \\
(76 \%)\end{array}$ & $\begin{array}{c}555 \\
(75 \%)\end{array}$ & $\begin{array}{c}628 \\
(75 \%)\end{array}$ & $\begin{array}{c}2772 \\
(76 \%)\end{array}$ & $\begin{array}{c}879 \\
(24 \%)\end{array}$ & \\
\hline \multicolumn{8}{|l|}{ Endline (3.5 yr.) follow-up } \\
\hline Main survey & $\begin{array}{l}3,879 \\
(88 \%)\end{array}$ & $\begin{array}{l}1,902 \\
(87 \%)\end{array}$ & $\begin{array}{l}1,855 \\
(86 \%)\end{array}$ & $\begin{array}{l}1,874 \\
(87 \%)\end{array}$ & $\begin{array}{l}9,510 \\
(87 \%)\end{array}$ & $\begin{array}{l}1,369 \\
(13 \%)\end{array}$ & \\
\hline
\end{tabular}

Abbreviations: mos., months; yr., year.

a Percentages are number of respondents to a survey divided by total sample for the respective survey. P-values are $0.285,0.672,0.135,0.906$, and 0.238 for baseline main, baseline biomarker, midline main, midline biomarker, and endline survey.

b Total across 4 insurance access groups.

c Non-response is the number of observations for which no respondent was recorded in the survey. Percentage non-response is that number divided by total sample for respective survey. 
Table A3. Respondent and response rate by module and insurance access group.

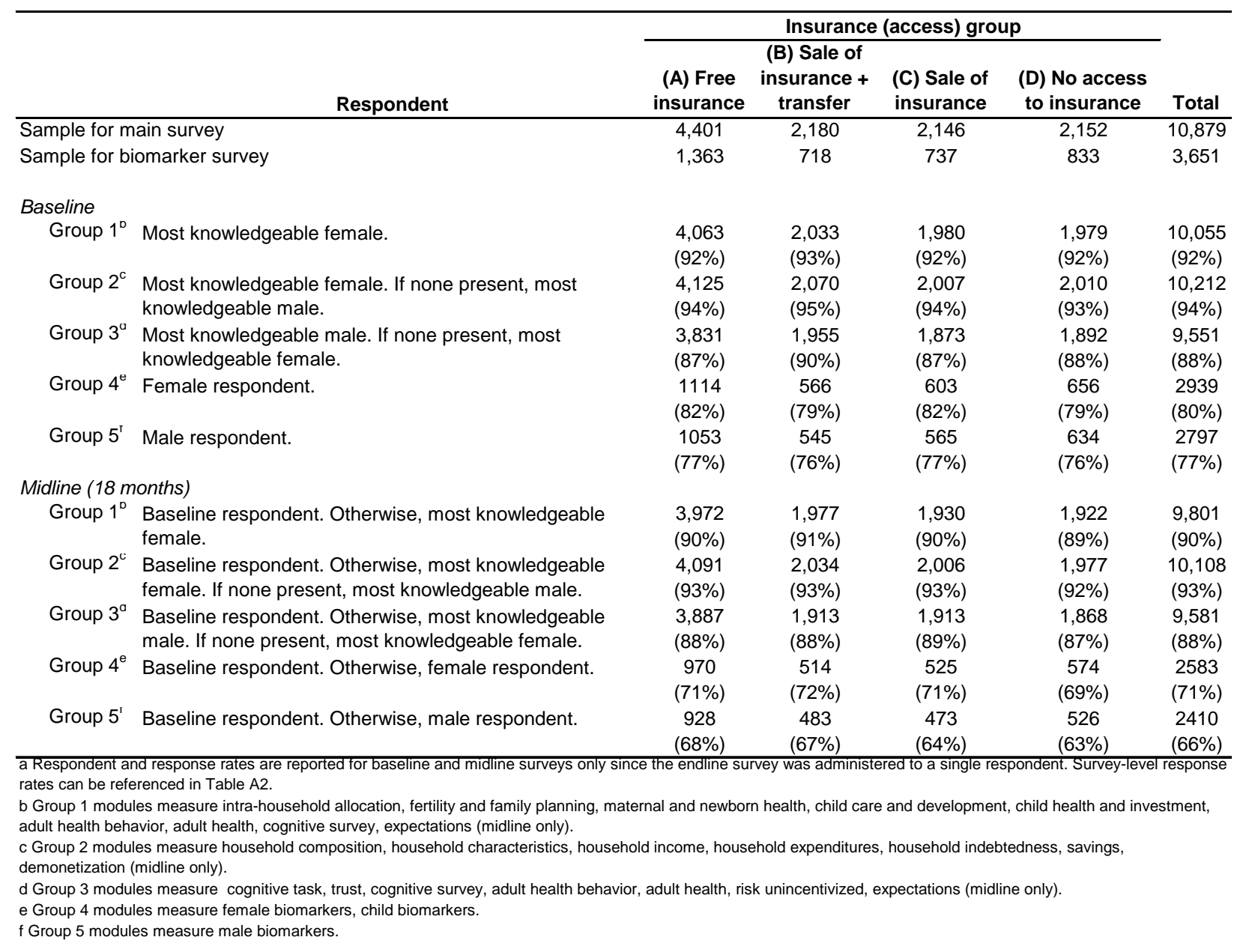


Table A4. Direct and indirect effects of insurance access on insurance enrollment, interacted with household budget at baseline. ${ }^{a}$

\begin{tabular}{|c|c|c|c|}
\hline & Direct effect & Spillover effect & Total effect \\
\hline & $\begin{array}{c}\text { Coefficient } \\
(95 \% \mathrm{Cl})\end{array}$ & $\begin{array}{c}\text { Coefficient } \\
(95 \% \mathrm{Cl})\end{array}$ & $\begin{array}{c}\text { Coefficient } \\
(95 \% \mathrm{Cl})\end{array}$ \\
\hline & P-value & P-value & P-value \\
\hline \multirow[t]{3}{*}{ (A) Free insurance } & $72.96 \%$ & $6.88 \%$ & $79.15 \%$ \\
\hline & (58.95\% to $86.98 \%)$ & $(-9.37 \%$ to $23.13 \%)$ & (77.04\% to $81.27 \%)$ \\
\hline & 0.000 & 0.406 & 0.000 \\
\hline (B) Sale of insurance & $65.01 \%$ & $5.04 \%$ & $69.55 \%$ \\
\hline \multirow[t]{2}{*}{+ transfer } & (43.21\% to $86.81 \%)$ & $(-20.99 \%$ to $31.07 \%)$ & $(65.88 \%$ to $73.22 \%)$ \\
\hline & 0.000 & 0.704 & 0.000 \\
\hline \multirow[t]{3}{*}{ (C) Sale of insurance } & $46.80 \%$ & $14.03 \%$ & $59.43 \%$ \\
\hline & (20.31\% to $73.30 \%)$ & $(-18.48 \%$ to $46.54 \%)$ & (53.89\% to $64.98 \%)$ \\
\hline & 0.001 & 0.397 & 0.000 \\
\hline (A) Free insurance & $-0.02 \%$ & $0.02 \%$ & $0.00 \%$ \\
\hline \multirow[t]{2}{*}{ x hhld. expenditure } & $(-0.10 \%$ to $0.06 \%)$ & $(-0.07 \%$ to $0.12 \%)$ & $(-0.01 \%$ to $0.02 \%)$ \\
\hline & 0.655 & 0.601 & 0.588 \\
\hline (B) Sale of insurance & $0.02 \%$ & $0.01 \%$ & $0.03 \%$ \\
\hline \multirow[t]{2}{*}{+ transfer $x$ hhld. expenditure } & $(-0.11 \%$ to $0.16 \%)$ & $(-0.15 \%$ to $0.17 \%)$ & (0.01\% to $0.05 \%)$ \\
\hline & 0.756 & 0.879 & 0.003 \\
\hline (C) Sale of insurance & $0.02 \%$ & $0.00 \%$ & $0.02 \%$ \\
\hline \multirow[t]{2}{*}{ x hhld. expenditure } & $(-0.17 \%$ to $0.20 \%)$ & $(-0.24 \%$ to $0.24 \%)$ & $(-0.03 \%$ to $0.07 \%)$ \\
\hline & 0.862 & 0.984 & 0.432 \\
\hline $\mathrm{N}$ & 9080 & 9080 & 9080 \\
\hline
\end{tabular}

Abbreviations: $\mathrm{Cl}$, confidence interval; hhld, household.

a Each observation is a household. Treatment variables are household assignments: free insurance (A), sale of insurance + cash transfer (B), sale of insurance (C). The household budget was estimated by adding all non-medical expenditures together. Estimates are intent-to-treat effects; all models estimated with OLS. Each treatment arm was interacted with the share of the village allocated to $A, B$, or C (combined). Standard errors were clustered at the village level. Coefficients were transformed to show percentage point changes from the control group D. Enrollment rate is zero in group D. The direct effect only includes the coefficient on treatment A, B, or C. The spillover effect is the estimated effect on a treated household of assigning all other sample households in the village to the same treatment. The total effect is calculated as the sum of the treatment coefficient, the share $A B C$, and their interaction. The total effect is constructed as the sum of the direct effect and $0.9^{\star}$ (spillover effect). 
Table A5. Reasons given for respondents' inability to use RSBY insurance card, by survey and

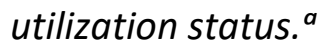

\begin{tabular}{|c|c|c|c|c|}
\hline & \multicolumn{2}{|c|}{ Midline (18 months) } & \multicolumn{2}{|c|}{ Endline ( 3.5 years) } \\
\hline & $\begin{array}{l}\text { Did not try to } \\
\text { use RSBY } \\
\text { (N=2551) }\end{array}$ & $\begin{array}{c}\text { Tried but } \\
\text { failed to use } \\
\text { RSBY } \\
(\mathrm{N}=160)\end{array}$ & $\begin{array}{c}\text { Did not try to } \\
\text { use RSBY } \\
\text { (N=2763) }\end{array}$ & $\begin{array}{c}\text { Tried but } \\
\text { failed to use } \\
\text { RSBY } \\
(\mathrm{N}=84) \\
\end{array}$ \\
\hline Forgot papers at home & $13 \%$ & $10 \%$ & $9 \%$ & $2 \%$ \\
\hline Has not received papers & $5 \%$ & $3 \%$ & $21 \%$ & $1 \%$ \\
\hline Didn't know card could be used for this purpose & $15 \%$ & $13 \%$ & $20 \%$ & $2 \%$ \\
\hline Patient wasn't on the card & $2 \%$ & $1 \%$ & $1 \%$ & $1 \%$ \\
\hline Card used up & $1 \%$ & $1 \%$ & $0 \%$ & $0 \%$ \\
\hline Didn't want to use card for treatment & $21 \%$ & $9 \%$ & $1 \%$ & $6 \%$ \\
\hline Doctor didn't accept card & $15 \%$ & $55 \%$ & $9 \%$ & $69 \%$ \\
\hline Card machine didn't work & $2 \%$ & $1 \%$ & $1 \%$ & $8 \%$ \\
\hline Treatment not covered & $5 \%$ & $8 \%$ & $2 \%$ & $7 \%$ \\
\hline Hospital that accepted card was too far & $3 \%$ & $6 \%$ & $0 \%$ & $1 \%$ \\
\hline Didn't know card would reduce payments & $3 \%$ & $3 \%$ & $2 \%$ & $0 \%$ \\
\hline Didn't know card would make treatment free & $12 \%$ & $6 \%$ & $3 \%$ & $0 \%$ \\
\hline Other reasons & $2 \%$ & $0 \%$ & $2 \%$ & $10 \%$ \\
\hline Didn't know where to use card & & & $30 \%$ & $5 \%$ \\
\hline Didn't know how to use card & & & $29 \%$ & $6 \%$ \\
\hline Insurance company didn't accept card & & & $1 \%$ & $12 \%$ \\
\hline Didn't need to use card & & & $2 \%$ & $1 \%$ \\
\hline Didn't trust doctor would accept card & & & $3 \%$ & $1 \%$ \\
\hline Didn't trust the card would work & & & $3 \%$ & $0 \%$ \\
\hline
\end{tabular}

Abbreviations: RSBY, Rashtriya Swasthya Bima Yojana.

a Table only includes respondents who enrolled in RSBY insurance. At midline, all respondents who reported having an RSBY card were asked about utilizations attempts. At endline, all respondents whose households had a serious health event were asked about utilization attempts. Percentages do not add up to 100 as respondents were allowed to report multiple reasons. 
Table A6. Effect of insurance access on health outcomes at midline (18 months post-intervention). ${ }^{a}$

\begin{tabular}{|c|c|c|c|c|c|c|c|c|c|c|c|}
\hline & & & \multicolumn{3}{|c|}{ (A) Free insurance } & \multicolumn{3}{|c|}{ (B) Sale of insurance + transfer } & \multicolumn{3}{|c|}{ (C) Sale of insurance } \\
\hline & & & Direct & Spillover & Total & Direct & Spillover & Total & Direct & Spillover & Total \\
\hline & $\mathbf{N}$ & $\begin{array}{l}\text { Control } \\
\text { mean }^{b} \\
\text { (SD) }\end{array}$ & $\begin{array}{c}\text { Coefficient } \\
\text { (95\% Cl) } \\
\text { P-valuec }^{c}\end{array}$ & $\begin{array}{c}\text { Coefficient } \\
\text { (95\% Cl) } \\
\text { P-value }\end{array}$ & $\begin{array}{c}\text { Coefficient } \\
\text { (95\% Cl) } \\
\text { P-value }\end{array}$ & $\begin{array}{c}\text { Coefficient } \\
\text { (95\% Cl) } \\
\text { P-value }\end{array}$ & $\begin{array}{c}\text { Coefficient } \\
\text { (95\% Cl) } \\
\text { P-value }\end{array}$ & $\begin{array}{c}\text { Coefficient } \\
(95 \% \mathrm{Cl}) \\
\text { P-value }\end{array}$ & $\begin{array}{c}\text { Coefficient } \\
\text { (95\% Cl) } \\
\text { P-value }\end{array}$ & $\begin{array}{c}\text { Coefficient } \\
\text { (95\% Cl) } \\
\text { P-value }\end{array}$ & $\begin{array}{c}\text { Coefficient } \\
\text { (95\% Cl) } \\
\text { P-value }\end{array}$ \\
\hline \multicolumn{12}{|l|}{ Health value } \\
\hline \multirow[t]{2}{*}{ Good or very good health ${ }^{\mathrm{e}}$} & 18983 & $\begin{array}{c}0.662 \\
(0.473)\end{array}$ & $\begin{array}{c}0.055 \\
(-0.024 \text { to } 0.134)\end{array}$ & $\begin{array}{c}-0.091 \\
(-0.229 \text { to } 0.046)\end{array}$ & $\begin{array}{c}-0.027 \\
(-0.146 \text { to } 0.092)\end{array}$ & $\begin{array}{c}0.061 \\
(-0.074 \text { to } 0.197)\end{array}$ & $\begin{array}{c}-0.046 \\
(-0.225 \text { to } 0.133)\end{array}$ & $\begin{array}{c}0.020 \\
(-0.099 \text { to } 0.139)\end{array}$ & $\begin{array}{c}0.146 \\
(0.000 \text { to } 0.291)\end{array}$ & $\begin{array}{c}-0.192 \\
(-0.387 \text { to } 0.002)\end{array}$ & $\begin{array}{c}-0.027 \\
(-0.146 \text { to } 0.091)\end{array}$ \\
\hline & & & .18 & .19 & .65 & .38 & .62 & .74 & .05 & .05 & .65 \\
\hline \multirow[t]{2}{*}{ Very good health $^{\mathrm{e}}$} & 18983 & $\begin{array}{c}0.155 \\
(0.362)\end{array}$ & $\begin{array}{c}0.064 \\
(-0.006 \text { to } 0.134)\end{array}$ & $\begin{array}{c}-0.086 \\
(-0.212 \text { to } 0.039)\end{array}$ & $\begin{array}{c}-0.014 \\
(-0.137 \text { to } 0.110)\end{array}$ & $\begin{array}{c}0.044 \\
(-0.091 \text { to } 0.179)\end{array}$ & $\begin{array}{c}-0.038 \\
(-0.223 \text { to } 0.146)\end{array}$ & $\begin{array}{c}0.009 \\
(-0.118 \text { to } 0.137)\end{array}$ & $\begin{array}{c}0.043 \\
(-0.091 \text { to } 0.177)\end{array}$ & $\begin{array}{c}-0.033 \\
(-0.216 \text { to } 0.150)\end{array}$ & $\begin{array}{c}0.013 \\
(-0.116 \text { to } 0.142)\end{array}$ \\
\hline & & & .07 & .18 & .83 & .52 & .68 & .89 & .53 & .72 & .84 \\
\hline \multirow[t]{2}{*}{ Poor or very poor health ${ }^{e}$} & 18983 & $\begin{array}{c}0.056 \\
(0.231)\end{array}$ & $\begin{array}{c}-0.012 \\
(-0.059 \text { to } 0.035)\end{array}$ & $\begin{array}{c}-0.022 \\
(-0.081 \text { to } 0.037)\end{array}$ & $\begin{array}{c}-0.032 \\
(-0.099 \text { to } 0.035)\end{array}$ & $\begin{array}{c}-0.029 \\
(-0.094 \text { to } 0.037)\end{array}$ & $\begin{array}{c}-0.006 \\
(-0.082 \text { to } 0.070)\end{array}$ & $\begin{array}{c}-0.034 \\
(-0.101 \text { to } 0.033)\end{array}$ & $\begin{array}{c}-0.012 \\
(-0.087 \text { to } 0.063)\end{array}$ & $\begin{array}{c}-0.020 \\
(-0.109 \text { to } 0.069)\end{array}$ & $\begin{array}{c}-0.030 \\
(-0.099 \text { to } 0.039)\end{array}$ \\
\hline & & & .62 & .46 & .35 & .39 & .87 & .32 & .75 & .66 & .39 \\
\hline \multirow[t]{2}{*}{ Very poor health ${ }^{\mathrm{e}}$} & 18983 & $\begin{array}{c}0.008 \\
(0.090)\end{array}$ & $\begin{array}{c}-0.000 \\
(-0.020 \text { to } 0.019)\end{array}$ & $\begin{array}{c}-0.004 \\
(-0.024 \text { to } 0.017)\end{array}$ & $\begin{array}{c}-0.003 \\
(-0.016 \text { to } 0.010)\end{array}$ & $\begin{array}{c}0.008 \\
(-0.013 \text { to } 0.028)\end{array}$ & $\begin{array}{c}-0.014 \\
(-0.035 \text { to } 0.006)\end{array}$ & $\begin{array}{c}-0.005 \\
(-0.018 \text { to } 0.007)\end{array}$ & $\begin{array}{c}0.002 \\
(-0.022 \text { to } 0.027)\end{array}$ & $\begin{array}{c}-0.005 \\
(-0.031 \text { to } 0.021)\end{array}$ & $\begin{array}{c}-0.003 \\
(-0.015 \text { to } 0.010)\end{array}$ \\
\hline & & & .00 & .72 & .60 & .47 & .16 & .40 & .86 & .69 & .69 \\
\hline \multicolumn{12}{|l|}{ Chronic disease } \\
\hline \multirow[t]{2}{*}{ Told had hypertension } & 18939 & $\begin{array}{c}0.190 \\
(0.392)\end{array}$ & $\begin{array}{c}0.028 \\
(-0.063 \text { to } 0.118)\end{array}$ & $\begin{array}{c}-0.098 \\
(-0.194 \text { to }-0.001)\end{array}$ & $\begin{array}{c}-0.060 \\
(-0.132 \text { to } 0.011)\end{array}$ & $\begin{array}{c}-0.140 \\
(-0.253 \text { to }-0.027)\end{array}$ & $\begin{array}{c}0.114 \\
(-0.022 \text { to } 0.249)\end{array}$ & $\begin{array}{c}-0.038 \\
(-0.112 \text { to } 0.037)\end{array}$ & $\begin{array}{c}-0.026 \\
(-0.130 \text { to } 0.078)\end{array}$ & $\begin{array}{c}-0.032 \\
(-0.154 \text { to } 0.090)\end{array}$ & $\begin{array}{c}-0.055 \\
(-0.127 \text { to } 0.017)\end{array}$ \\
\hline & & & .55 & .05 & .10 & .02 & .10 & .32 & .63 & .61 & .14 \\
\hline \multirow[t]{2}{*}{$\begin{array}{l}\text { Takes medication } \\
\text { for hypertension }\end{array}$} & 18960 & $\begin{array}{c}0.131 \\
(0.338)\end{array}$ & $\begin{array}{c}-0.018 \\
(-0.091 \text { to } 0.055)\end{array}$ & $\begin{array}{c}-0.044 \\
(-0.133 \text { to } 0.046)\end{array}$ & $\begin{array}{c}-0.057 \\
(-0.122 \text { to } 0.007)\end{array}$ & $\begin{array}{c}-0.125 \\
(-0.218 \text { to }-0.032)\end{array}$ & $\begin{array}{c}0.089 \\
(-0.029 \text { to } 0.207)\end{array}$ & $\begin{array}{c}-0.045 \\
(-0.112 \text { to } 0.022)\end{array}$ & $\begin{array}{c}-0.082 \\
(-0.166 \text { to } 0.002)\end{array}$ & $\begin{array}{c}0.037 \\
(-0.063 \text { to } 0.137)\end{array}$ & $\begin{array}{c}-0.048 \\
(-0.114 \text { to } 0.017)\end{array}$ \\
\hline & & & .63 & .34 & .08 & .009 & .14 & .19 & .06 & .47 & .15 \\
\hline \multirow[t]{2}{*}{ Told had diabetes ${ }^{\dagger}$} & 18913 & $\begin{array}{c}0.068 \\
(0.252)\end{array}$ & $\begin{array}{c}-0.005 \\
(-0.051 \text { to } 0.042)\end{array}$ & $\begin{array}{c}-0.003 \\
(-0.058 \text { to } 0.051)\end{array}$ & $\begin{array}{c}-0.008 \\
(-0.053 \text { to } 0.038)\end{array}$ & $\begin{array}{c}-0.040 \\
(-0.114 \text { to } 0.033)\end{array}$ & $\begin{array}{c}0.047 \\
(-0.037 \text { to } 0.130)\end{array}$ & $\begin{array}{c}0.002 \\
(-0.045 \text { to } 0.049)\end{array}$ & $\begin{array}{c}-0.032 \\
(-0.103 \text { to } 0.038)\end{array}$ & $\begin{array}{c}0.033 \\
(-0.037 \text { to } 0.104)\end{array}$ & $\begin{array}{c}-0.002 \\
(-0.048 \text { to } 0.043)\end{array}$ \\
\hline & & & .85 & .90 & .75 & .28 & .28 & .95 & .37 & .36 & .92 \\
\hline \multirow{2}{*}{ for diabetes } & 18948 & $\begin{array}{c}0.050 \\
(0.217)\end{array}$ & $\begin{array}{c}-0.002 \\
(-0.040 \text { to } 0.037)\end{array}$ & $\begin{array}{c}-0.000 \\
(-0.045 \text { to } 0.045)\end{array}$ & $\begin{array}{c}-0.002 \\
(-0.041 \text { to } 0.037)\end{array}$ & $\begin{array}{c}-0.023 \\
(-0.084 \text { to } 0.039)\end{array}$ & $\begin{array}{c}0.030 \\
(-0.043 \text { to } 0.103)\end{array}$ & $\begin{array}{c}0.004 \\
(-0.037 \text { to } 0.046)\end{array}$ & $\begin{array}{c}-0.027 \\
(-0.088 \text { to } 0.034)\end{array}$ & $\begin{array}{c}0.025 \\
(-0.038 \text { to } 0.088)\end{array}$ & $\begin{array}{c}-0.004 \\
(-0.044 \text { to } 0.036)\end{array}$ \\
\hline & & & .93 & .99 & .92 & .47 & .42 & .84 & .39 & .43 & .84 \\
\hline \multirow[t]{2}{*}{ Takes insulin for diabetes } & 18952 & $\begin{array}{c}0.018 \\
(0.133)\end{array}$ & $\begin{array}{c}-0.001 \\
(-0.022 \text { to } 0.020)\end{array}$ & $\begin{array}{c}0.019 \\
(-0.003 \text { to } 0.041)\end{array}$ & $\begin{array}{c}0.016 \\
(-0.005 \text { to } 0.038)\end{array}$ & $\begin{array}{c}-0.016 \\
(-0.047 \text { to } 0.015)\end{array}$ & $\begin{array}{c}0.042 \\
\text { (0.006 to } 0.077)\end{array}$ & $\begin{array}{c}0.021 \\
(-0.002 \text { to } 0.044)\end{array}$ & $\begin{array}{c}-0.006 \\
(-0.038 \text { to } 0.027)\end{array}$ & $\begin{array}{c}0.027 \\
(-0.008 \text { to } 0.062)\end{array}$ & $\begin{array}{c}0.019 \\
(-0.003 \text { to } 0.041)\end{array}$ \\
\hline & & & .94 & .09 & .14 & .30 & .02 & .08 & .73 & .13 & .10 \\
\hline \multirow[t]{2}{*}{ for diabetes } & 18962 & $\begin{array}{c}0.046 \\
(0.210)\end{array}$ & $\begin{array}{c}-0.000 \\
(-0.035 \text { to } 0.034)\end{array}$ & $\begin{array}{c}-0.003 \\
(-0.050 \text { to } 0.045)\end{array}$ & $\begin{array}{c}-0.003 \\
(-0.044 \text { to } 0.038)\end{array}$ & $\begin{array}{c}-0.044 \\
(-0.100 \text { to } 0.011)\end{array}$ & $\begin{array}{c}0.055 \\
(-0.009 \text { to } 0.118)\end{array}$ & $\begin{array}{c}0.005 \\
(-0.037 \text { to } 0.047)\end{array}$ & $\begin{array}{c}-0.038 \\
(-0.097 \text { to } 0.021)\end{array}$ & $\begin{array}{c}0.047 \\
(-0.013 \text { to } 0.106)\end{array}$ & $\begin{array}{c}0.005 \\
(-0.037 \text { to } 0.046)\end{array}$ \\
\hline & & & .98 & .91 & .89 & .12 & .09 & .82 & .21 & .12 & .83 \\
\hline \multirow[t]{2}{*}{ Told had cancer $^{\dagger}$} & 18946 & $\begin{array}{c}0.004 \\
(0.064)\end{array}$ & $\begin{array}{c}-0.006 \\
(-0.017 \text { to } 0.004)\end{array}$ & $\begin{array}{c}0.010 \\
(-0.002 \text { to } 0.021)\end{array}$ & $\begin{array}{c}0.002 \\
(-0.005 \text { to } 0.010)\end{array}$ & $\begin{array}{c}-0.003 \\
(-0.021 \text { to } 0.014)\end{array}$ & $\begin{array}{c}0.009 \\
(-0.012 \text { to } 0.029)\end{array}$ & $\begin{array}{c}0.004 \\
(-0.003 \text { to } 0.012)\end{array}$ & $\begin{array}{c}-0.005 \\
(-0.020 \text { to } 0.011)\end{array}$ & $\begin{array}{c}0.005 \\
(-0.012 \text { to } 0.023)\end{array}$ & $\begin{array}{c}0.000 \\
(-0.007 \text { to } 0.007)\end{array}$ \\
\hline & & & .22 & .11 & .54 & .69 & .40 & .23 & .55 & .55 & .94 \\
\hline \multirow[t]{2}{*}{$\begin{array}{l}\text { Received cancer } \\
\text { treatment past } 1 \mathrm{yr} .\end{array}$} & 18998 & $\begin{array}{c}0.002 \\
(0.049)\end{array}$ & $\begin{array}{c}0.002 \\
(-0.007 \text { to } 0.011)\end{array}$ & $\begin{array}{c}-0.002 \\
(-0.012 \text { to } 0.008)\end{array}$ & $\begin{array}{c}0.000 \\
(-0.006 \text { to } 0.006)\end{array}$ & $\begin{array}{c}-0.004 \\
(-0.012 \text { to } 0.005)\end{array}$ & $\begin{array}{c}0.005 \\
(-0.004 \text { to } 0.013)\end{array}$ & $\begin{array}{c}0.000 \\
(-0.005 \text { to } 0.006)\end{array}$ & $\begin{array}{c}0.003 \\
(-0.012 \text { to } 0.017)\end{array}$ & $\begin{array}{c}-0.002 \\
(-0.019 \text { to } 0.015)\end{array}$ & $\begin{array}{c}0.001 \\
(-0.005 \text { to } 0.007)\end{array}$ \\
\hline & & & .66 & .67 & .95 & .38 & .28 & .87 & .70 & .81 & .75 \\
\hline \multirow[t]{2}{*}{ Told had lung disease ${ }^{f}$} & 18907 & $\begin{array}{c}0.034 \\
(0.181)\end{array}$ & $\begin{array}{c}-0.017 \\
(-0.057 \text { to } 0.022)\end{array}$ & $\begin{array}{c}0.014 \\
(-0.020 \text { to } 0.048)\end{array}$ & $\begin{array}{c}-0.005 \\
(-0.038 \text { to } 0.028)\end{array}$ & $\begin{array}{c}0.012 \\
(-0.043 \text { to } 0.068)\end{array}$ & $\begin{array}{c}-0.022 \\
(-0.077 \text { to } 0.033)\end{array}$ & $\begin{array}{c}-0.008 \\
(-0.041 \text { to } 0.026)\end{array}$ & $\begin{array}{c}0.002 \\
(-0.053 \text { to } 0.056)\end{array}$ & $\begin{array}{c}-0.002 \\
(-0.060 \text { to } 0.056)\end{array}$ & $\begin{array}{c}-0.000 \\
(-0.034 \text { to } 0.034)\end{array}$ \\
\hline & & & .39 & .42 & .78 & .66 & .43 & .66 & .95 & .95 & .99 \\
\hline
\end{tabular}


Table A6 (cont'd). Effect of insurance access on health outcomes at midline (18 months post-intervention). ${ }^{a}$

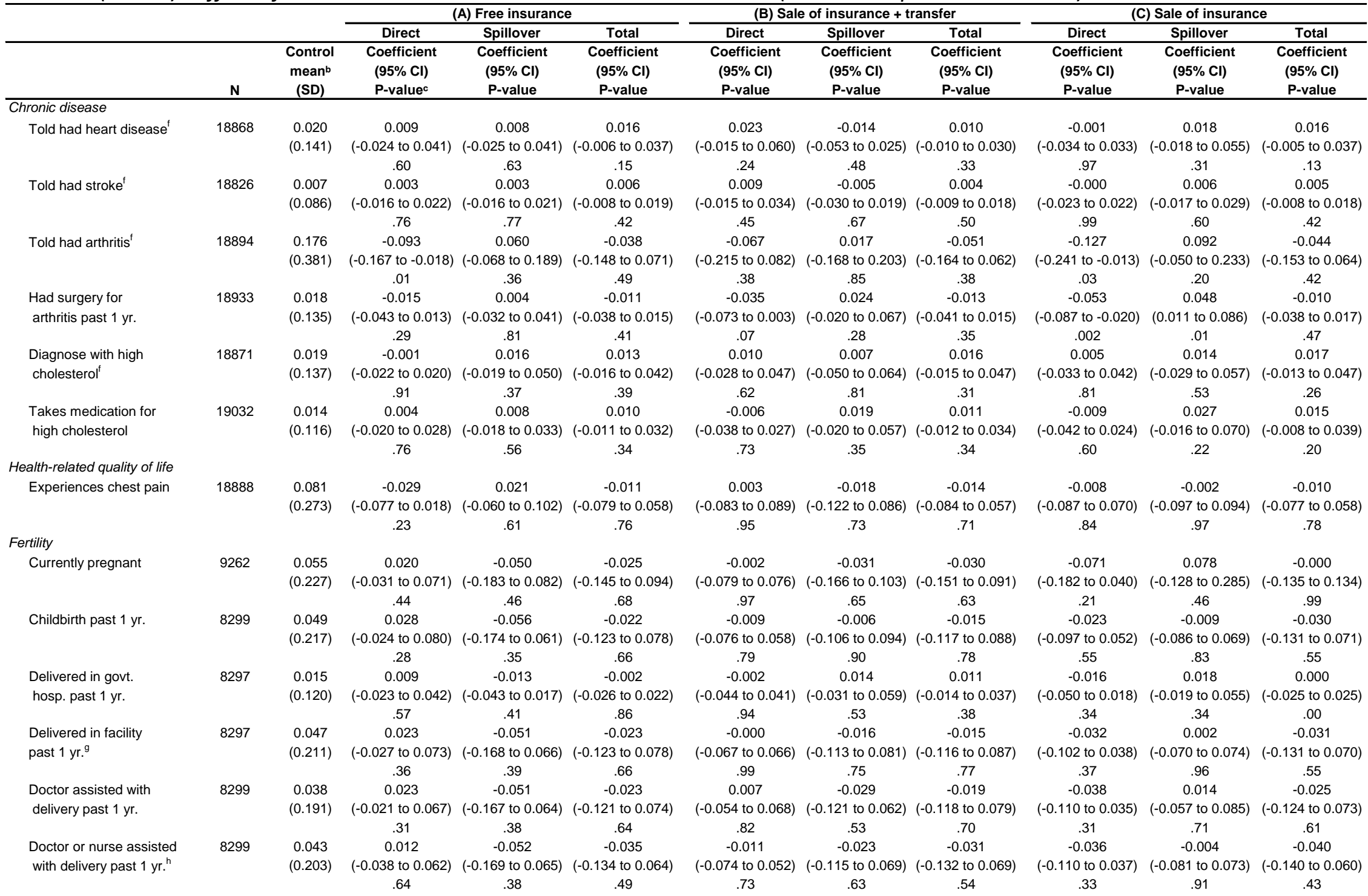


Table A6 (cont'd). Effect of insurance access on health outcomes at midline (18 months post-intervention). ${ }^{a}$

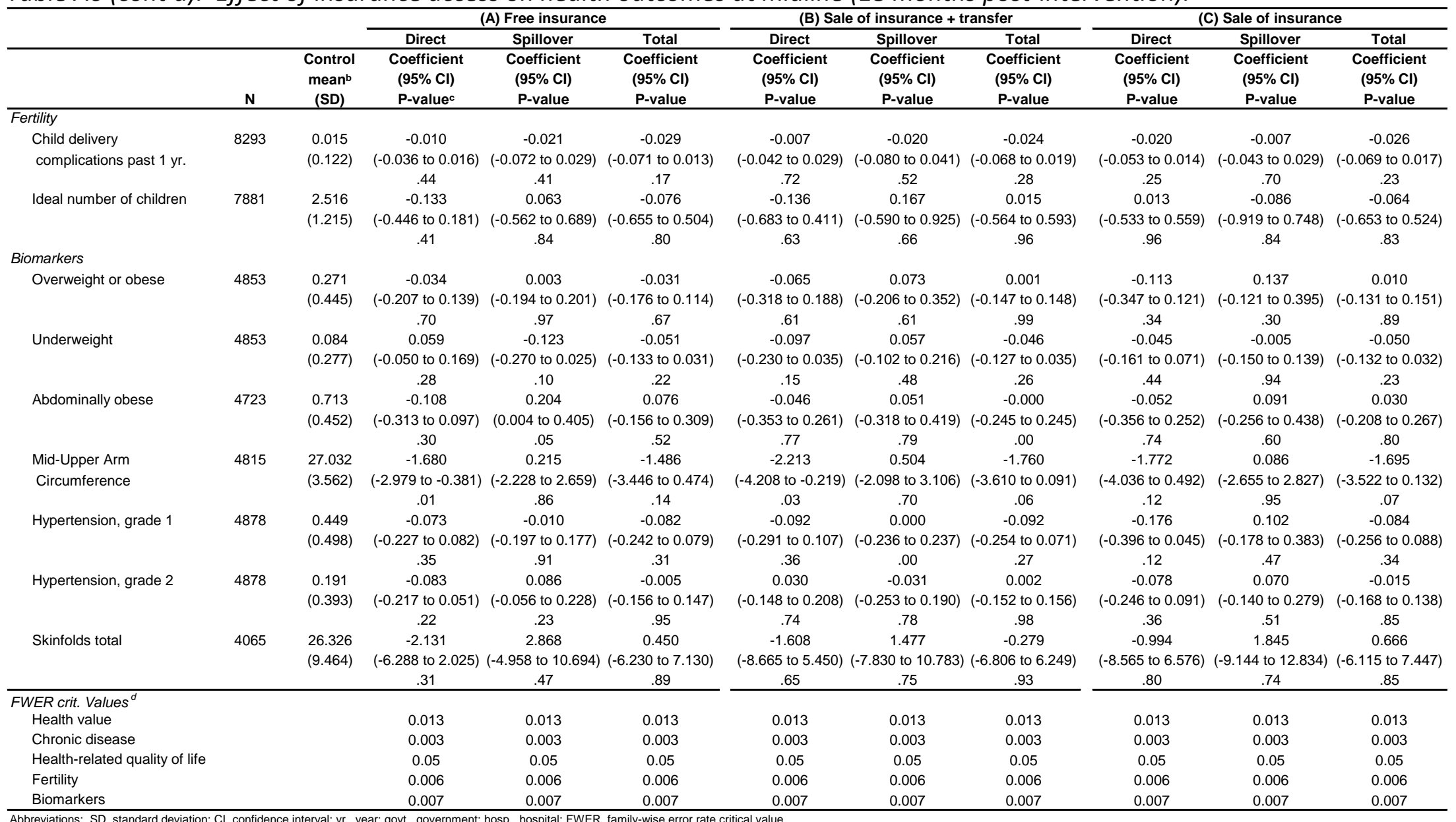

a Each observation is a respondent. There may be up to 2 respondents in a household: male and female. Data for male and female respondents were pooled and a common effect for both sexes is presented. A dummy for sex was included in the regression (not reported) as a control. Observations are weighted so each household has equal weight. Treatment variables are household assignments: free insurance (A), sale of insurance + cash transfer (B), sale of insurance (C). All models estimated with OLS; estimates are intent-to-treat (ITT) effects. household of assigning all other sample households in the village to the same treatment. The total effect is constructed as the sum of the direct effect and $0.9 *$ (spillover effect).

b Mean and standard deviation in the control group are statistics from the unenrolled group.

c P-values are given for individual outcome variables.

d FWER critical values are critical values for a targeted false discovery rate amongst all outcomes under a heading (e.g., chronic conditions)

e Indicator variables based on a five-point Likert scale for seff-reported health. very good - 1 , good - 2 fair - 3 poor - 4 , very poor - 5 .

f The doctor diagnoses are indicator variables for whether the respondent said a physician told the respondent that he or she had the conditions listed.

$g$ A facility refers to any kind of a medical facility, such as a public/private hospital or a clinic.

n Nurses also include midwives. 
Table A7. Effect of insurance access on health outcomes at endline (3.5 years post-intervention). ${ }^{a}$

\begin{tabular}{|c|c|c|c|c|c|c|c|c|c|c|c|}
\hline & & & \multicolumn{3}{|c|}{ (A) Free insurance } & \multicolumn{3}{|c|}{ (B) Sale of insurance + transfer } & \multicolumn{3}{|c|}{ (C) Sale of insurance } \\
\hline & & & Direct & Spillover & Total & Direct & Spillover & Total & Direct & Spillover & Total \\
\hline & $\mathrm{N}$ & $\begin{array}{c}\text { Control } \\
\text { mean } \\
\text { (SD) }\end{array}$ & $\begin{array}{l}\text { Coefficient } \\
\text { (95\% Cl) }\end{array}$ & $\begin{array}{l}\text { Coefficient } \\
\text { (95\% CI) } \\
\text { P-value }\end{array}$ & $\begin{array}{l}\text { Coefficient } \\
\text { (95\% CI) } \\
\text { P-value }\end{array}$ & $\begin{array}{l}\text { Coefficient } \\
\text { (95\% Cl) } \\
\text { P-value }\end{array}$ & $\begin{array}{l}\text { Coefficient } \\
\text { (95\% Cl) } \\
\text { P-value }\end{array}$ & $\begin{array}{l}\text { Coefficient } \\
\text { (95\% Cl) } \\
\text { P-value }\end{array}$ & $\begin{array}{l}\text { Coefficient } \\
\text { (95\% CI) } \\
\text { P-value }\end{array}$ & $\begin{array}{l}\text { Coefficient } \\
\text { (95\% CI) } \\
\text { P-value }\end{array}$ & $\begin{array}{l}\text { Coefficient } \\
\text { (95\% CI) } \\
\text { P-value }\end{array}$ \\
\hline ealth value & & & & & & & & & & & \\
\hline Sickness ${ }^{e}$ & 9356 & $\begin{array}{c}0.134 \\
(0.340)\end{array}$ & $\begin{array}{c}-0.018 \\
(-0.102 \text { to } 0.066) \\
.67\end{array}$ & $\begin{array}{c}0.014 \\
(-0.079 \text { to } 0.107) \\
.77\end{array}$ & $\begin{array}{c}-0.006 \\
(-0.088 \text { to } 0.076) \\
.89\end{array}$ & $\begin{array}{c}-0.026 \\
(-0.140 \text { to } 0.087) \\
.65\end{array}$ & $\begin{array}{c}0.010 \\
(-0.124 \text { to } 0.145) \\
.88\end{array}$ & $\begin{array}{c}-0.017 \\
(-0.101 \text { to } 0.067) \\
.69\end{array}$ & $\begin{array}{c}-0.030 \\
(-0.148 \text { to } 0.088) \\
.62\end{array}$ & $\begin{array}{c}0.036 \\
(-0.119 \text { to } 0.191) \\
.65\end{array}$ & $\begin{array}{c}0.003 \\
(-0.085 \text { to } 0.090) \\
.95\end{array}$ \\
\hline Good or very good health & 9492 & $\begin{array}{c}0.516 \\
(0.500)\end{array}$ & $\begin{array}{c}0.014 \\
(-0.138 \text { to } 0.166) \\
86\end{array}$ & $\begin{array}{c}-0.011 \\
(-0.185 \text { to } 0.164) \\
90\end{array}$ & $\begin{array}{c}0.005 \\
(-0.139 \text { to } 0.148) \\
95\end{array}$ & $\begin{array}{c}-0.172 \\
(-0.365 \text { to } 0.021) \\
08\end{array}$ & $\begin{array}{c}0.225 \\
\text { (0.009 to } 0.442) \\
04\end{array}$ & $\begin{array}{c}0.031 \\
(-0.114 \text { to } 0.176)\end{array}$ & $\begin{array}{c}0.015 \\
(-0.176 \text { to } 0.207) \\
87\end{array}$ & $\begin{array}{c}-0.026 \\
(-0.239 \text { to } 0.187)\end{array}$ & $\begin{array}{c}-0.008 \\
(-0.153 \text { to } 0.137)\end{array}$ \\
\hline Very good health ${ }^{\dagger}$ & 9492 & $\begin{array}{c}0.076 \\
(0.265)\end{array}$ & $\begin{array}{c}0.027 \\
(-0.059 \text { to } 0.112) \\
.54\end{array}$ & $\begin{array}{c}-0.120 \\
(-0.233 \text { to }-0.006) \\
.04\end{array}$ & $\begin{array}{c}-0.081 \\
(-0.163 \text { to } 0.001) \\
.05\end{array}$ & $\begin{array}{c}-0.061 \\
(-0.164 \text { to } 0.042) \\
.24\end{array}$ & $\begin{array}{c}-0.016 \\
(-0.121 \text { to } 0.090) \\
.77\end{array}$ & $\begin{array}{c}-0.075 \\
(-0.159 \text { to } 0.008) \\
.08\end{array}$ & $\begin{array}{c}-0.047 \\
(-0.136 \text { to } 0.043) \\
.30\end{array}$ & $\begin{array}{c}-0.043 \\
(-0.147 \text { to } 0.061) \\
.41\end{array}$ & $\begin{array}{c}-0.086 \\
(-0.170 \text { to }-0.002) \\
.04\end{array}$ \\
\hline Poor or very poor health ${ }^{\dagger}$ & 9492 & $\begin{array}{c}0.102 \\
(0.303)\end{array}$ & $\begin{array}{c}-0.033 \\
(-0.128 \text { to } 0.061) \\
.49\end{array}$ & $\begin{array}{c}0.036 \\
(-0.058 \text { to } 0.130) \\
.45\end{array}$ & $\begin{array}{c}-0.001 \\
(-0.084 \text { to } 0.083) \\
.99\end{array}$ & $\begin{array}{c}-0.036 \\
(-0.156 \text { to } 0.084) \\
.55\end{array}$ & $\begin{array}{c}0.033 \\
(-0.090 \text { to } 0.157) \\
.60\end{array}$ & $\begin{array}{c}-0.006 \\
(-0.092 \text { to } 0.079) \\
.89\end{array}$ & $\begin{array}{c}-0.037 \\
(-0.159 \text { to } 0.084) \\
.54\end{array}$ & $\begin{array}{c}0.038 \\
(-0.085 \text { to } 0.161) \\
.54\end{array}$ & $\begin{array}{c}-0.003 \\
(-0.088 \text { to } 0.082) \\
.94\end{array}$ \\
\hline Very poor health $^{\dagger}$ & 9492 & $\begin{array}{c}0.021 \\
(0.143)\end{array}$ & $\begin{array}{c}-0.042 \\
(-0.085 \text { to } 0.001) \\
.05\end{array}$ & $\begin{array}{c}0.006 \\
(-0.030 \text { to } 0.042) \\
.75\end{array}$ & $\begin{array}{c}-0.037 \\
(-0.082 \text { to } 0.009) \\
.11\end{array}$ & $\begin{array}{c}-0.052 \\
(-0.102 \text { to }-0.002) \\
.04\end{array}$ & $\begin{array}{c}0.021 \\
(-0.033 \text { to } 0.075) \\
.44\end{array}$ & $\begin{array}{c}-0.033 \\
(-0.080 \text { to } 0.013) \\
.16\end{array}$ & $\begin{array}{c}-0.033 \\
(-0.086 \text { to } 0.020) \\
.22\end{array}$ & $\begin{array}{c}-0.007 \\
(-0.054 \text { to } 0.039) \\
.75\end{array}$ & $\begin{array}{c}-0.040 \\
(-0.086 \text { to } 0.006) \\
.08\end{array}$ \\
\hline hronic & & & & & & & & & & & \\
\hline ypertension $^{9}$ & 9476 & $\begin{array}{c}0.233 \\
(0.423)\end{array}$ & $\begin{array}{c}-0.039 \\
(-0.151 \text { to } 0.073) \\
.50\end{array}$ & $\begin{array}{c}0.013 \\
(-0.104 \text { to } 0.130) \\
.83\end{array}$ & $\begin{array}{c}-0.027 \\
(-0.132 \text { to } 0.078) \\
.61\end{array}$ & $\begin{array}{c}-0.110 \\
(-0.260 \text { to } 0.040) \\
.15\end{array}$ & $\begin{array}{c}0.099 \\
(-0.059 \text { to } 0.257) \\
.22\end{array}$ & $\begin{array}{c}-0.021 \\
(-0.128 \text { to } 0.087) \\
.70\end{array}$ & $\begin{array}{c}-0.169 \\
(-0.331 \text { to }-0.006) \\
.04\end{array}$ & $\begin{array}{c}0.178 \\
(0.010 \text { to } 0.346) \\
.04\end{array}$ & $\begin{array}{c}-0.008 \\
(-0.118 \text { to } 0.102) \\
.88\end{array}$ \\
\hline $\begin{array}{l}\text { Takes medication } \\
\text { for hypertension }\end{array}$ & 9495 & $\begin{array}{c}0.197 \\
(0.398)\end{array}$ & $\begin{array}{c}-0.041 \\
(-0.146 \text { to } 0.064) \\
.44\end{array}$ & $\begin{array}{c}0.037 \\
(-0.068 \text { to } 0.142) \\
.49\end{array}$ & $\begin{array}{c}-0.008 \\
(-0.105 \text { to } 0.089) \\
.87\end{array}$ & $\begin{array}{c}-0.062 \\
(-0.200 \text { to } 0.076) \\
.38\end{array}$ & $\begin{array}{c}0.064 \\
(-0.084 \text { to } 0.213) \\
.40\end{array}$ & $\begin{array}{c}-0.004 \\
(-0.103 \text { to } 0.094) \\
.93\end{array}$ & $\begin{array}{c}-0.117 \\
(-0.261 \text { to } 0.027) \\
.11\end{array}$ & $\begin{array}{c}0.141 \\
(-0.008 \text { to } 0.290) \\
.06\end{array}$ & $\begin{array}{c}0.010 \\
(-0.090 \text { to } 0.110) \\
.84\end{array}$ \\
\hline Told had diabetes $^{g}$ & 9479 & $\begin{array}{c}0.121 \\
(0.326)\end{array}$ & $\begin{array}{c}-0.049 \\
(-0.143 \text { to } 0.045) \\
30\end{array}$ & $\begin{array}{c}-0.019 \\
(-0.113 \text { to } 0.075) \\
70\end{array}$ & $\begin{array}{c}-0.066 \\
(-0.145 \text { to } 0.013)\end{array}$ & $\begin{array}{c}-0.131 \\
(-0.248 \text { to }-0.015) \\
03\end{array}$ & $\begin{array}{c}0.082 \\
(-0.039 \text { to } 0.202) \\
18\end{array}$ & $\begin{array}{c}-0.058 \\
(-0.139 \text { to } 0.024)\end{array}$ & $\begin{array}{c}-0.149 \\
(-0.260 \text { to }-0.037) \\
0.9\end{array}$ & $\begin{array}{c}0.104 \\
(-0.006 \text { to } 0.214) \\
06\end{array}$ & $\begin{array}{c}-0.055 \\
(-0.135 \text { to } 0.025)\end{array}$ \\
\hline $\begin{array}{l}\text { Takes oral medication } \\
\text { for diabetes }\end{array}$ & 9499 & & $\begin{array}{c}-0.046 \\
(-0.140 \text { to } 0.047) \\
33\end{array}$ & $\begin{array}{c}-0.003 \\
(-0.093 \text { to } 0.088) \\
95\end{array}$ & $\begin{array}{c}-0.049 \\
(-0.120 \text { to } 0.022) \\
18\end{array}$ & $\begin{array}{c}-0.109 \\
(-0.216 \text { to }-0.002)\end{array}$ & $\begin{array}{c}0.073 \\
(-0.044 \text { to } 0.189)\end{array}$ & $\begin{array}{c}-0.044 \\
(-0.117 \text { to } 0.029) \\
24\end{array}$ & $\begin{array}{c}-0.126 \\
(-0.228 \text { to }-0.023) \\
02\end{array}$ & $\begin{array}{c}0.098 \\
(-0.007 \text { to } 0.203) \\
07\end{array}$ & $\begin{array}{c}-0.037 \\
(-0.109 \text { to } 0.034)\end{array}$ \\
\hline Takes insulin for diabetes & 9489 & $\begin{array}{c}0.024 \\
(0.152)\end{array}$ & $\begin{array}{c}0.018 \\
(-0.019 \text { to } 0.054) \\
35\end{array}$ & $\begin{array}{c}-0.007 \\
(-0.045 \text { to } 0.030)\end{array}$ & $\begin{array}{c}0.011 \\
(-0.018 \text { to } 0.040)\end{array}$ & $\begin{array}{c}0.018 \\
(-0.034 \text { to } 0.070)\end{array}$ & $\begin{array}{c}-0.007 \\
(-0.065 \text { to } 0.050)\end{array}$ & $\begin{array}{c}0.011 \\
(-0.018 \text { to } 0.041)\end{array}$ & $\begin{array}{c}-0.005 \\
(-0.054 \text { to } 0.044) \\
84\end{array}$ & $\begin{array}{c}0.022 \\
(-0.030 \text { to } 0.073)\end{array}$ & $\begin{array}{c}0.014 \\
(-0.016 \text { to } 0.045)\end{array}$ \\
\hline $\begin{array}{l}\text { Follows a special diet } \\
\text { for diabetes }\end{array}$ & 9495 & $\begin{array}{l}0.077 \\
(0.267)\end{array}$ & $\begin{array}{c}-0.035 \\
(-0.116 \text { to } 0.046)\end{array}$ & $\begin{array}{c}0.012 \\
(-0.064 \text { to } 0.088)\end{array}$ & $\begin{array}{c}-0.024 \\
(-0.088 \text { to } 0.040)\end{array}$ & $\begin{array}{c}-0.075 \\
(-0.170 \text { to } 0.021)\end{array}$ & $\begin{array}{c}0.064 \\
(-0.037 \text { to } 0.165)\end{array}$ & $\begin{array}{c}-0.017 \\
(-0.082 \text { to } 0.048)\end{array}$ & $\begin{array}{c}-0.073 \\
(-0.166 \text { to } 0.021)\end{array}$ & $\begin{array}{c}0.064 \\
(-0.036 \text { to } 0.164)\end{array}$ & $\begin{array}{c}-0.015 \\
(-0.079 \text { to } 0.049)\end{array}$ \\
\hline Told had cancer ${ }^{9}$ & 9470 & $\begin{array}{c}0.004 \\
(0.065)\end{array}$ & $\begin{array}{c}-0.005 \\
(-0.021 \text { to } 0.010) \\
.51\end{array}$ & $\begin{array}{c}0.012 \\
(-0.001 \text { to } 0.025) \\
.06\end{array}$ & $\begin{array}{c}0.006 \\
(-0.006 \text { to } 0.017) \\
.35\end{array}$ & $\begin{array}{c}0.006 \\
(-0.022 \text { to } 0.034) \\
.68\end{array}$ & $\begin{array}{c}0.001 \\
(-0.035 \text { to } 0.037) \\
.96\end{array}$ & $\begin{array}{c}0.007 \\
(-0.006 \text { to } 0.020) \\
.32\end{array}$ & $\begin{array}{c}0.001 \\
(-0.015 \text { to } 0.017) \\
.93\end{array}$ & $\begin{array}{c}0.001 \\
(-0.013 \text { to } 0.016) \\
.84\end{array}$ & $\begin{array}{c}0.002 \\
(-0.010 \text { to } 0.014) \\
.73\end{array}$ \\
\hline $\begin{array}{l}\text { Treated for cancer } \\
\text { past } 1 \text { yr. }\end{array}$ & 9496 & $\begin{array}{c}0.002 \\
(0.046)\end{array}$ & $\begin{array}{c}0.000 \\
(-0.012 \text { to } 0.012) \\
.99\end{array}$ & $\begin{array}{c}0.000 \\
(-0.011 \text { to } 0.011) \\
.94\end{array}$ & $\begin{array}{c}0.000 \\
(-0.007 \text { to } 0.008) \\
.91\end{array}$ & $\begin{array}{c}-0.007 \\
(-0.017 \text { to } 0.002) \\
.14\end{array}$ & $\begin{array}{c}0.009 \\
(-0.001 \text { to } 0.019) \\
.08\end{array}$ & $\begin{array}{c}0.001 \\
(-0.007 \text { to } 0.009) \\
.87\end{array}$ & $\begin{array}{c}-0.002 \\
(-0.013 \text { to } 0.010) \\
.75\end{array}$ & $\begin{array}{c}0.002 \\
(-0.009 \text { to } 0.013) \\
.69\end{array}$ & $\begin{array}{c}0.000 \\
(-0.008 \text { to } 0.008) \\
.97\end{array}$ \\
\hline Told had lung disease ${ }^{g}$ & 9479 & $\begin{array}{c}0.060 \\
(0.238)\end{array}$ & $\begin{array}{c}-0.035 \\
(-0.094 \text { to } 0.024) \\
.25\end{array}$ & $\begin{array}{c}0.021 \\
(-0.035 \text { to } 0.077) \\
.46\end{array}$ & $\begin{array}{c}-0.016 \\
(-0.062 \text { to } 0.030) \\
.50\end{array}$ & $\begin{array}{c}-0.004 \\
(-0.077 \text { to } 0.069) \\
.91\end{array}$ & $\begin{array}{c}-0.017 \\
(-0.104 \text { to } 0.071) \\
.71\end{array}$ & $\begin{array}{c}-0.019 \\
(-0.068 \text { to } 0.030) \\
.45\end{array}$ & $\begin{array}{c}-0.038 \\
(-0.115 \text { to } 0.039) \\
.34\end{array}$ & $\begin{array}{c}0.017 \\
(-0.056 \text { to } 0.091) \\
.64\end{array}$ & $\begin{array}{c}-0.022 \\
(-0.069 \text { to } 0.025) \\
.35\end{array}$ \\
\hline
\end{tabular}


Table A7 (cont'd). Effect of insurance access on health outcomes at endline (3.5 years post-intervention). ${ }^{a}$

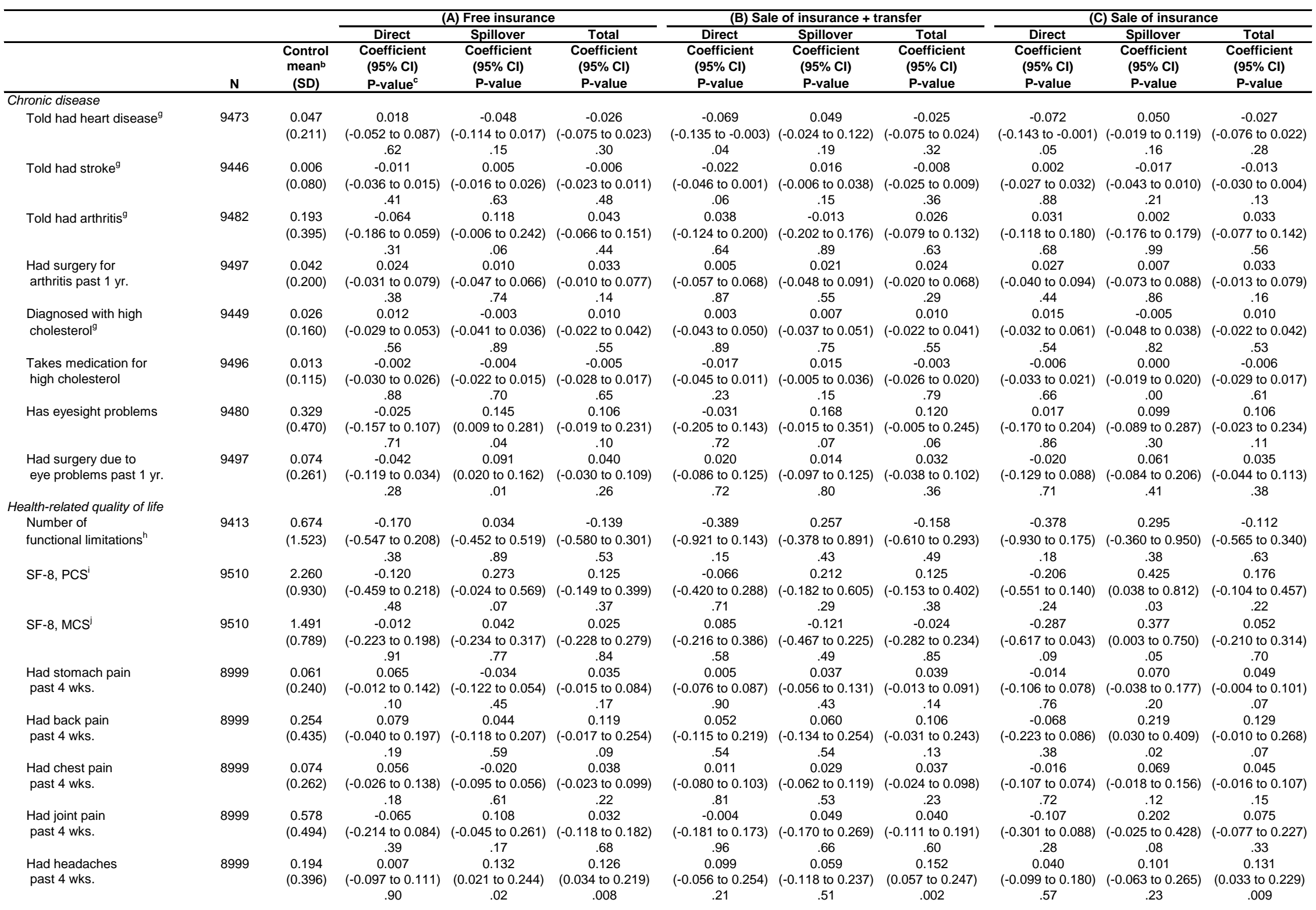


Table A7 (cont'd). Effect of insurance access on health outcomes at endline (3.5 years post-intervention). ${ }^{a}$

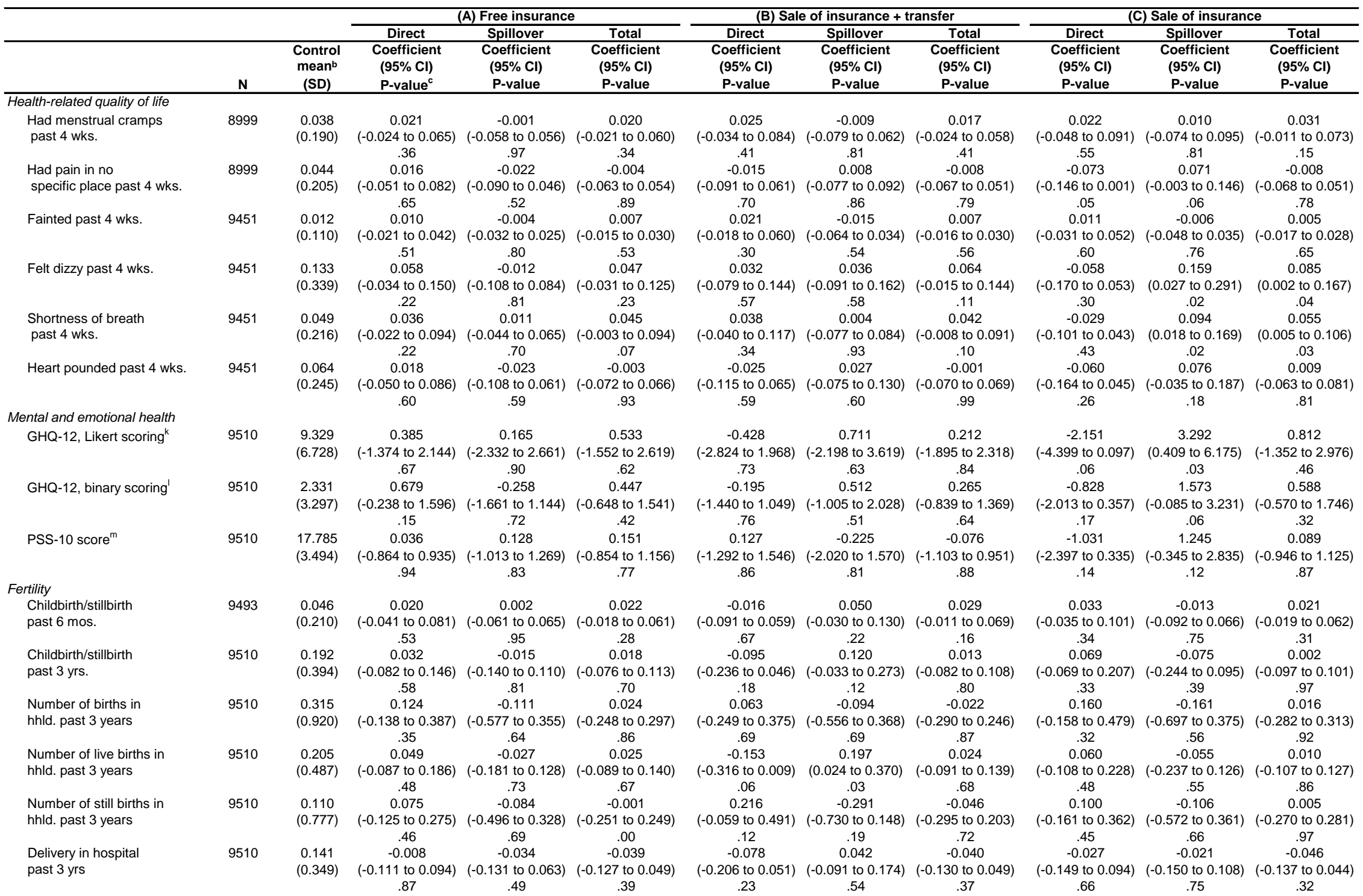


Table A7 (cont'd). Effect of insurance access on health outcomes at endline (3.5 years post-intervention). ${ }^{a}$

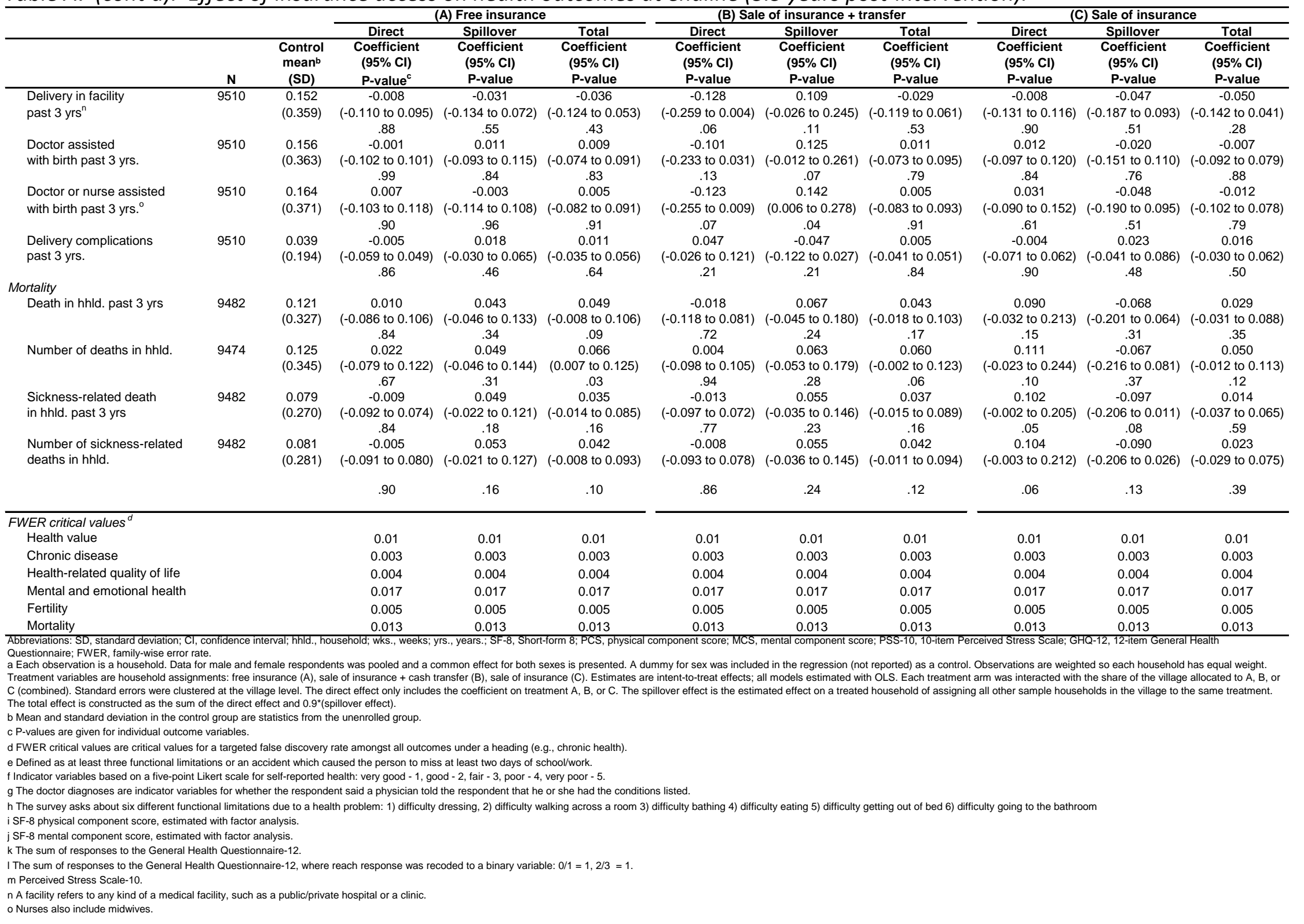


Table A8. Number of significant health outcomes per category. ${ }^{a}$

\begin{tabular}{|c|c|c|c|c|c|c|c|c|c|}
\hline \multirow{3}{*}{\multicolumn{2}{|c|}{ Health category }} & \multicolumn{4}{|c|}{18 months (Midline) } & \multicolumn{4}{|c|}{3.5 years (Endline) } \\
\hline & & \multicolumn{3}{|l|}{ ITT } & \multirow{2}{*}{$\begin{array}{c}\text { TOT } \\
\\
\text { Enrollment }\end{array}$} & \multicolumn{3}{|l|}{ ITT } & \multirow[b]{2}{*}{ Enrollment } \\
\hline & & $\begin{array}{c}\text { (A) Free } \\
\text { insurance }\end{array}$ & $\begin{array}{l}\text { (B) Sale of } \\
\text { insurance } \\
+ \text { transfer }\end{array}$ & $\begin{array}{l}\text { (C) Sale of } \\
\text { insurance }\end{array}$ & & $\begin{array}{c}\text { (A) Free } \\
\text { insurance }\end{array}$ & $\begin{array}{l}\text { (B) Sale of } \\
\text { insurance } \\
+ \text { transfer } \\
\end{array}$ & $\begin{array}{l}\text { (C) Sale of } \\
\text { insurance }\end{array}$ & \\
\hline \multirow[t]{4}{*}{ Self-reported health } & Total outcomes & 1 & 1 & 1 & 1 & 2 & 2 & 2 & 2 \\
\hline & Significant direct effect & 0 & 0 & 1 & 1 & 0 & 1 & 0 & 1 \\
\hline & Significant spillover effect & 0 & 0 & 0 & 1 & 1 & 1 & 0 & 0 \\
\hline & Significant total & 0 & 0 & 0 & 0 & 1 & 0 & 1 & 1 \\
\hline \multirow[t]{4}{*}{ Chronic disease } & Total outcomes & 15 & 15 & 15 & 15 & 17 & 17 & 17 & 17 \\
\hline & Significant direct effect & 1 & 2 & 2 & 1 & 0 & 3 & 4 & 0 \\
\hline & Significant spillover effect & 1 & 1 & 1 & 0 & 2 & 0 & 1 & 0 \\
\hline & Significant total & 0 & 1 & 0 & 1 & 0 & 1 & 0 & 1 \\
\hline \multirow[t]{4}{*}{ Quality of life } & Total outcomes & 1 & 1 & 1 & 1 & 14 & 14 & 14 & 14 \\
\hline & Significant direct effect & 0 & 0 & 0 & 0 & 0 & 0 & 0 & 0 \\
\hline & Significant spillover effect & 0 & 0 & 0 & 0 & 1 & 0 & 5 & 0 \\
\hline & Significant total & 0 & 0 & 0 & 0 & 1 & 1 & 4 & 2 \\
\hline \multirow{4}{*}{$\begin{array}{l}\text { Mental and behavioral } \\
\text { health }\end{array}$} & Total outcomes & 0 & 0 & 0 & 0 & 3 & 3 & 3 & 3 \\
\hline & Significant direct effect & & & & & 0 & 0 & 0 & 0 \\
\hline & Significant spillover effect & & & & & 0 & 0 & 1 & 0 \\
\hline & Significant total & & & & & 0 & 0 & 0 & 0 \\
\hline \multirow[t]{4}{*}{ Childbirth } & Total outcomes & 8 & 8 & 8 & 8 & 10 & 10 & 10 & 10 \\
\hline & Significant direct effect & 0 & 0 & 0 & 0 & 0 & 0 & 0 & 0 \\
\hline & Significant spillover effect & 0 & 0 & 0 & 0 & 0 & 2 & 0 & 0 \\
\hline & Significant total & 0 & 0 & 0 & 0 & 0 & 0 & 0 & 0 \\
\hline \multirow[t]{4}{*}{ Biomarkers } & Total outcomes & 7 & 7 & 7 & 7 & 0 & 0 & 0 & 0 \\
\hline & Significant direct effect & 1 & 1 & 0 & 1 & & & & \\
\hline & Significant spillover effect & 1 & 0 & 0 & 0 & & & & \\
\hline & Significant total & 0 & 0 & 0 & 0 & & & & \\
\hline \multirow[t]{4}{*}{ Mortality } & Total outcomes & 0 & 0 & 0 & 0 & 4 & 4 & 4 & 4 \\
\hline & Significant direct effect & & & & & 0 & 0 & 0 & 0 \\
\hline & Significant spillover effect & & & & & 0 & 0 & 0 & 0 \\
\hline & Significant total & & & & & 1 & 0 & 0 & 0 \\
\hline
\end{tabular}

Treatment variables are household assignments: free insurance (A), sale of insurance + cash transfer (B), sale of insurance (C). Estimates are intent-to-treat effects; all models estimated with OLS.

significant health out interacted with the share of the village alloc 
Table A9. Effect of failed use at midline on attempted use at endline. ${ }^{a}$

\begin{tabular}{|c|c|c|c|c|c|c|}
\hline & \multicolumn{3}{|c|}{ All households } & \multicolumn{3}{|c|}{ Enrolled households } \\
\hline & $\begin{array}{c}\text { Coefficient } \\
\text { (95\% Cl) } \\
\text { P-value }\end{array}$ & $\begin{array}{c}\text { Coefficient } \\
\text { (95\% Cl) } \\
\text { P-value }\end{array}$ & $\begin{array}{c}\text { Coefficient } \\
\text { (95\% Cl) } \\
\text { P-value }\end{array}$ & $\begin{array}{c}\text { Coefficient } \\
(95 \% \mathrm{Cl}) \\
\text { P-value }\end{array}$ & $\begin{array}{c}\text { Coefficient } \\
\text { (95\% Cl) } \\
\text { P-value }\end{array}$ & $\begin{array}{c}\text { Coefficient } \\
\text { (95\% Cl) } \\
\text { P-value }\end{array}$ \\
\hline \multirow[t]{3}{*}{ Failed use at $18 \mathrm{mos}}$. & -0.002 & -0.004 & 0.035 & -0.003 & 0.006 & 0.081 \\
\hline & $(-0.019$ to 0.015$)$ & $(-0.006$ to -0.001$)$ & $(-0.110$ to 0.181$)$ & $(-0.026$ to 0.020$)$ & $(-0.057$ to 0.070$)$ & (-0.141 to 0.303$)$ \\
\hline & .81 & .01 & .63 & .78 & .84 & .47 \\
\hline \multirow[t]{3}{*}{ Failed use at 18 mos. x A } & & -0.009 & -0.005 & & -0.019 & -0.017 \\
\hline & & $(-0.030$ to 0.012$)$ & $(-0.039$ to 0.029$)$ & & $(-0.088$ to 0.050$)$ & $(-0.089$ to 0.054$)$ \\
\hline & & .39 & .78 & & .59 & .64 \\
\hline \multirow[t]{3}{*}{ Failed use at 18 mos. x B } & & 0.011 & 0.014 & & 0.004 & 0.003 \\
\hline & & $(-0.034$ to 0.056$)$ & $(-0.029$ to 0.058$)$ & & $(-0.081$ to 0.088$)$ & $(-0.082$ to 0.088$)$ \\
\hline & & .62 & .52 & & .93 & .94 \\
\hline \multirow[t]{3}{*}{ Failed use at 18 mos. x C } & & 0.011 & 0.013 & & & \\
\hline & & $(-0.045$ to 0.067$)$ & $(-0.042$ to 0.068$)$ & & & \\
\hline & & .70 & .63 & & & \\
\hline \multirow[t]{3}{*}{ (A) Free insurance } & & 0.019 & 0.019 & & -0.001 & -0.001 \\
\hline & & (0.013 to 0.026$)$ & (0.012 to 0.026$)$ & & $(-0.011$ to 0.009$)$ & $(-0.012$ to 0.009$)$ \\
\hline & & $\mathrm{p}<.001$ & $p<.001$ & & .85 & .83 \\
\hline \multirow{3}{*}{$\begin{array}{l}\text { (B) Sale of insurance } \\
+ \text { transfer }\end{array}$} & & 0.011 & 0.011 & & -0.007 & -0.007 \\
\hline & & (0.005 to 0.018$)$ & (0.004 to 0.017$)$ & & $(-0.019$ to 0.004$)$ & $(-0.019$ to 0.004$)$ \\
\hline & & $\mathrm{p}<.001$ & $p<.001$ & & .21 & .21 \\
\hline \multirow[t]{3}{*}{ (C) Sale of insurance } & & 0.018 & 0.017 & & & \\
\hline & & (0.010 to 0.025$)$ & (0.010 to 0.025$)$ & & & \\
\hline & & $\mathrm{p}<.001$ & $p<.001$ & & & \\
\hline \multirow[t]{3}{*}{ Failed use at 18 mos. $x$ share $A B C$} & & & -0.051 & & & -0.090 \\
\hline & & & $(-0.241$ to 0.139$)$ & & & $(-0.361$ to 0.181$)$ \\
\hline & & & .60 & & & .51 \\
\hline \multirow{3}{*}{ Share $A B C$} & & & 0.004 & & & 0.007 \\
\hline & & & $(-0.019$ to 0.027$)$ & & & $(-0.036$ to 0.050$)$ \\
\hline & & & .75 & & & .76 \\
\hline \multirow[t]{3}{*}{ Spillover } & & & -0.047 & & & -0.083 \\
\hline & & & $(-0.240$ to 0.145$)$ & & & $(-0.359$ to 0.192$)$ \\
\hline & & & 0.629 & & & 0.552 \\
\hline \multirow[t]{3}{*}{ Total } & & & -0.012 & & & -0.002 \\
\hline & & & $(-0.062$ to 0.038$)$ & & & $(-0.100$ to 0.095$)$ \\
\hline & & & 0.639 & & & 0.960 \\
\hline $\mathrm{N}$ & 8891 & 8891 & 8891 & 5323 & 5323 & 5323 \\
\hline
\end{tabular}

a Each observation is a household. Treatment variables are household assignments: free insurance (A), sale of insurance + cash transfer (B), sale of insurance (C). Estimates are intent-toa Each observation is a household. Treatment variables are household assignments: free insurance (A), sale of insurance + cash transfer (B), sale of insurance (C). Estimates are intent-to-
treat effects; all models estimated with OLS. Each treatment arm was interacted with the share of the village allocated to A, B, or C (combined). Standard errors were clustered at the village level. Coefficients were transformed to show percentage point changes from the control group D. Enrollment rate is 0 in the control group D. The direct effect only includes the coefficient on treatment A, B, or C. The spillover effect is the estimated effect on a treated household of assigning all other sample households in the village to the same treatment. The total effect is calculated as the sum of the treatment coefficient, the share ABC, and their interaction. Failed use means that the household attempted to use RSBY to pay for care but were unable to (for many possible reasons, Table A5). 


\section{References}

Abaluck, J., M. Caceres Bravo, P. Hull and A. Starc (2021). "Mortality Effects and Choice Across Private Health Insurance Plans*." The Quarterly Journal of Economics 136(3): 1557-1610.

Alexander, D. (2020). "How do doctors respond to incentives? unintended consequences of paying doctors to reduce costs." Journal of Political Economy 128(11): 4046-4096.

Baicker, K., S. L. Taubman, H. L. Allen, M. Bernstein, J. H. Gruber, J. P. Newhouse, E. C. Schneider, B. J. Wright, A. M. Zaslavsky and A. N. Finkelstein (2013). "The Oregon Experiment Effects of Medicaid on Clinical Outcomes." New England Journal of Medicine 368(18): 17131722.

Banerjee, A., A. Finkelstein, R. Hanna, B. A. Olken, A. Ornaghi and S. Sumarto (2021). "The Challenges of Universal Health Insurance in Developing Countries: Experimental Evidence from Indonesia's National Health Insurance." American Economic Review.

Benjamini, Y. and D. Yekutieli (2001). "The control of the false discovery rate in multiple testing under dependency." Ann. Statist. 29(4): 1165-1188.

Berman, P. and R. Ahuja (2008). "Government health spending in India." Economic and Political Weekly 46: 26-27.

Black, B., J.-A. Espín-Sánchez, E. French and K. Litvak (2017). "The Long-Term Effect of Health Insurance on Near-Elderly Health and Mortality." American Journal of Health Economics 3(3): 281-311.

Black, B., A. Hollingsworth, L. Nunes and K. Simon (2019). The Effect of Health Insurance on Mortality: Power Analysis and What We Can Learn from the Affordable Care Act Coverage Expansions, National Bureau of Economic Research.

Chandra, A., E. Flack and Z. Obermeyer (2021). The health costs of cost-sharing, National Bureau of Economic Research.

Cohen, J. and P. Dupas (2010). "FREE DISTRIBUTION OR COST-SHARING? EVIDENCE FROM A RANDOMIZED MALARIA PREVENTION EXPERIMENT." Quarterly Journal of Economics 125(1).

Cohen, S., R. C. Kessler and L. U. Gordon (1997). Measuring stress: A guide for health and social scientists, Oxford University Press on Demand.

Das, J., J. Hammer and K. Leonard (2008). "The Quality of Medical Advice in Low-Income Countries." Journal of Economic Perspectives 22(2): 93-114. 
Das, J., A. Holla, V. Das, M. Mohanan, D. Tabak and B. Chan (2012). "In urban and rural India, a standardized patient study showed low levels of provider training and huge quality gaps." Health affairs 31(12): 2774-2784.

Das, J. and J. Leino (2011). "Evaluating the RSBY: Lessons from an Experimental Information Campaign." Economic \& Political Weekly 46(32): 85.

Deka, K. (2012). No free treatment in Assam's government hospitals. India Today.

Devadasan, N., T. Seshadri, M. Trivedi and B. Criel (2013). "Promoting universal financial protection: evidence from the Rashtriya Swasthya Bima Yojana (RSBY) in Gujarat, India." Health research policy and systems 11: 29-29.

Fenton, J. J., A. F. Jerant, K. D. Bertakis and P. Franks (2012). "The Cost of Satisfaction: A National Study of Patient Satisfaction, Health Care Utilization, Expenditures, and Mortality." Archives of Internal Medicine 172(5): 405-411.

Garg, S., K. K. Bebarta and N. Tripathi (2020). "Performance of India's national publicly funded health insurance scheme, Pradhan Mantri Jan Arogaya Yojana (PMJAY), in improving access and financial protection for hospital care: findings from household surveys in Chhattisgarh state." BMC Public Health 20(1): 949.

Goldin, J., I. Z. Lurie and J. McCubbin (2019). Health Insurance and Mortality: Experimental Evidence from Taxpayer Outreach, National Bureau of Economic Research.

Government of India and Ministry of Health and Family Welfare (2014-2015). National Health Accounts - Estimates for India 2014-2015.

Haushofer, J., M. Chemin, C. Jang and J. Abraham (2017). "Peace of mind: health insurance reduces stress and cortisol levels-evidence from a randomized experiment in Kenya."

Haushofer, J., M. Chemin, C. Jang and J. Abraham (2020). "Economic and psychological effects of health insurance and cash transfers: Evidence from a randomized experiment in Kenya." Journal of Development Economics 144: 102416.

Hines, J. R. and R. H. Thaler (1995). "The flypaper effect." Journal of economic perspectives 9(4): 217-226.

Hudgens, M. G. and M. E. Halloran (2008). "Toward Causal Inference With Interference." Journal of the American Statistical Association 103(482): 832-842. 
Huh, J. and J. Reif (2017). "Did Medicare Part D reduce mortality?" Journal of Health Economics 53: 17-37.

Imai, K., Z. Jiang and A. Malani (2019). Causal Inference with Interference and Noncompliance in Two-Stage Randomized Experiments.

Imai, K., G. King and N. Clayton (2009). "The Essential Role of Pair Matching in ClusterRandomized Experiments, with Application to the Mexican Universal Health Insurance Evaluation." Statistical Science 24(1): 29-53.

Kaestner, R. (2021). "Mortality and Science: A Comment on Two Articles on the Effects of Health Insurance on Mortality." Econ Journal Watch 18(2): 192.

King, G., E. Gakidou, K. Imai, J. Lakin, R. T. Moore, C. Nall, N. Ravishankar, M. Vargas, M. M. Téllez-Rojo and J. E. H. Ávila (2009). "Public policy for the poor? A randomised assessment of the Mexican universal health insurance programme." The Lancet 373(9673): 1447-1454.

Kling, J. R., J. B. Liebman and L. F. Katz (2007). "Experimental Analysis of Neighborhood Effects." Econometrica 75(1): 83-119.

Kruk, M. E., A. D. Gage, N. T. Joseph, G. Danaei, S. García-Saisó and J. A. Salomon (2018). "Mortality due to low-quality health systems in the universal health coverage era: a systematic analysis of amenable deaths in 137 countries." The Lancet 392(10160): 2203-2212.

La Forgia, G. and S. Nagpal (2012). Government-sponsored health insurance in India: Are you covered?, World Bank Publications.

Lang, L., L. Zhang, P. Zhang, Q. Li, J. Bian and Y. Guo (2018). "Evaluating the reliability and validity of SF-8 with a large representative sample of urban Chinese." Health and quality of life outcomes 16(1): 55.

Levine, D., R. Polimeni and I. Ramage (2016). "Insuring health or insuring wealth? An experimental evaluation of health insurance in rural Cambodia." Journal of Development Economics 119: 1-15.

Levy, H. and D. Meltzer (2008). "The Impact of Health Insurance on Health." Annual Review of Public Health 29(1): 399-409.

Liu, H., Q. Sun and Z. Zhao (2014). "Social learning and health insurance enrollment: Evidence from China's New Cooperative Medical Scheme." Journal of Economic Behavior \& Organization 97: 84-102. 
Miller, S., N. Johnson and L. R. Wherry (2021). "Medicaid and Mortality: New Evidence From Linked Survey and Administrative Data*." The Quarterly Journal of Economics 136(3): 17831829.

Mohanan, M., M. Vera-Hernández, V. Das, S. Giardili, J. D. Goldhaber-Fiebert, T. L. Rabin, S. S. Raj, J. I. Schwartz and A. Seth (2015). "The know-do gap in quality of health care for childhood diarrhea and pneumonia in rural India." JAMA pediatrics 169(4): 349-357.

Naghavi, M., A. A. Abajobir, C. Abbafati, K. M. Abbas, F. Abd-Allah, S. F. Abera, V. Aboyans, O. Adetokunboh, A. Afshin, A. Agrawal, A. Ahmadi, M. B. Ahmed, A. N. Aichour, M. T. E. Aichour, I. Aichour, S. Aiyar, F. Alahdab, Z. Al-Aly, K. Alam, N. Alam, T. Alam, K. A. Alene, A. Al-Eyadhy, S. D. Ali, R. Alizadeh-Navaei, J. M. Alkaabi, A. a. Alkerwi, F. Alla, P. Allebeck, C. Allen, R. Al-Raddadi, U. Alsharif, K. A. Altirkawi, N. Alvis-Guzman, A. T. Amare, E. Amini, W. Ammar, Y. A. Amoako, N. Anber, H. H. Andersen, C. L. Andrei, S. Androudi, H. Ansari, C. A. T. Antonio, P. Anwari, J. Ärnlöv, M. Arora, A. Artaman, K. K. Aryal, H. Asayesh, S. W. Asgedom, T. M. Atey, L. Avila-Burgos, E. F. G. Avokpaho, A. Awasthi, T. K. Babalola, U. Bacha, K. Balakrishnan, A. Barac, M. A. Barboza, S. L. Barker-Collo, S. Barquera, L. Barregard, L. H. Barrero, B. T. Baune, N. Bedi, E. Beghi, Y. Béjot, B. B. Bekele, M. L. Bell, J. R. Bennett, I. M. Bensenor, A. Berhane, E. Bernabé, B. D. Betsu, M. Beuran, S. Bhatt, S. Biadgilign, K. Bienhoff, B. Bikbov, D. Bisanzio, R. R. A. Bourne, N. J. K. Breitborde, L. N. B. Bulto, B. R. Bumgarner, Z. A. Butt, L. Cahuana-Hurtado, E. Cameron, J. C. Campuzano, J. Car, R. Cárdenas, J. J. Carrero, A. Carter, D. C. Casey, C. A. Castañeda-Orjuela, F. Catalá-López, F. J. Charlson, C. E. Chibueze, O. Chimed-Ochir, V. H. Chisumpa, A. A. Chitheer, D. J. Christopher, L. G. Ciobanu, M. Cirillo, A. J. Cohen, D. Colombara, C. Cooper, B. C. Cowie, M. H. Criqui, L. Dandona, R. Dandona, P. I. Dargan, J. das Neves, D. V. Davitoiu, K. Davletov, B. de Courten, B. K. Defo, L. Degenhardt, S. Deiparine, K. Deribe, A. Deribew, S. Dey, D. Dicker, E. L. Ding, S. Djalalinia, H. P. Do, D. T. Doku, D. Douwes-Schultz, T. R. Driscoll, M. Dubey, B. B. Duncan, M. Echko, Z. Z. El-Khatib, C. L. Ellingsen, A. Enayati, S. P. Ermakov, H. E. Erskine, S. Eskandarieh, A. Esteghamati, K. Estep, C. S. e. S. Farinha, A. Faro, F. Farzadfar, V. L. Feigin, S.-M. Fereshtehnejad, J. C. Fernandes, A. J. Ferrari, T. R. Feyissa, I. Filip, S. Finegold, F. Fischer, C. Fitzmaurice, A. D. Flaxman, N. Foigt, T. Frank, M. Fraser, N. Fullman, T. Fürst, J. M. Furtado, E. Gakidou, A. L. Garcia-Basteiro, T. Gebre, G. B. Gebregergs, T. T. Gebrehiwot, D. Y. Gebremichael, J. M. Geleijnse, R. Genova-Maleras, H. A. Gesesew, P. W. Gething, R. F. Gillum, A. Z. Giref, M. Giroud, G. Giussani, W. W. Godwin, A. L. Gold, E. M. Goldberg, P. N. Gona, S. V. Gopalani, H. N. Gouda, A. C. Goulart, M. Griswold, R. Gupta, T. Gupta, V. Gupta, P. C. Gupta, J. A. Haagsma, N. Hafezi-Nejad, A. D. Hailu, G. B. Hailu, R. R. Hamadeh, M. T. Hambisa, S. Hamidi, M. Hammami, J. Hancock, A. J. Handal, G. J. Hankey, Y. Hao, H. L. Harb, H. A. Hareri, M. S. Hassanvand, R. Havmoeller, S. I. Hay, F. He, M. T. Hedayati, N. J. Henry, I. B. Heredia-Pi, C. Herteliu, H. W. Hoek, M. Horino, N. Horita, H. D. Hosgood, S. Hostiuc, P. J. Hotez, D. G. Hoy, C. Huynh, K. M. Iburg, C. Ikeda, B. V. Ileanu, A. A. Irenso, C. M. S. Irvine, S. M. S. Islam, K. H. Jacobsen, N. Jahanmehr, M. B. Jakovljevic, M. Javanbakht, S. P. Jayaraman, P. Jeemon, V. Jha, D. John, C. O. Johnson, S. C. Johnson, J. B. Jonas, M. Jürisson, Z. Kabir, R. Kadel, A. Kahsay, R. Kamal, A. Karch, S. M. Karimi, C. Karimkhani, A. Kasaeian, N. A. Kassaw, N. J. Kassebaum, S. V. Katikireddi, N. Kawakami, P. N. Keiyoro, L. Kemmer, C. N. Kesavachandran, Y. S. Khader, E. A. Khan, Y.-H. Khang, A. T. A. Khoja, 
M. H. Khosravi, A. Khosravi, J. Khubchandani, A. A. Kiadaliri, C. Kieling, D. Kievlan, Y. J. Kim, D. Kim, R. W. Kimokoti, Y. Kinfu, N. Kissoon, M. Kivimaki, A. K. Knudsen, J. A. Kopec, S. Kosen, P. A. Koul, A. Koyanagi, X. R. Kulikoff, G. A. Kumar, P. Kumar, M. Kutz, H. H. Kyu, D. K. Lal, R. Lalloo, T. L. N. Lambert, Q. Lan, V. C. Lansingh, A. Larsson, P. H. Lee, J. Leigh, J. Leung, M. Levi, Y. Li, D. Li Kappe, X. Liang, M. L. Liben, S. S. Lim, P. Y. Liu, A. Liu, Y. Liu, R. Lodha, G. Logroscino, S. Lorkowski, P. A. Lotufo, R. Lozano, T. C. D. Lucas, S. Ma, E. R. K. Macarayan, E. R. Maddison, M. Magdy Abd El Razek, M. Majdan, R. Majdzadeh, A. Majeed, R. Malekzadeh, R. Malhotra, D. C. Malta, H. Manguerra, T. Manyazewal, C. C. Mapoma, L. B. Marczak, D. Markos, J. MartinezRaga, F. R. Martins-Melo, I. Martopullo, C. McAlinden, M. McGaughey, J. J. McGrath, S. Mehata, T. Meier, K. G. Meles, P. Memiah, Z. A. Memish, M. M. Mengesha, D. T. Mengistu, B. G. Menota, G. A. Mensah, T. J. Meretoja, A. Meretoja, A. Millear, T. R. Miller, S. Minnig, M. Mirarefin, E. M. Mirrakhimov, A. Misganaw, S. R. Mishra, I. A. Mohamed, K. A. Mohammad, A. Mohammadi, S. Mohammed, A. H. Mokdad, G. L. D. Mola, S. K. Mollenkopf, M. Molokhia, L. Monasta, J. C. Montañez, M. Montico, M. D. Mooney, M. Moradi-Lakeh, P. Moraga, L. Morawska, C. Morozoff, S. D. Morrison, C. Mountjoy-Venning, K. B. Mruts, K. Muller, G. V. S. Murthy, K. I. Musa, J. B. Nachega, A. Naheed, L. Naldi, V. Nangia, B. R. Nascimento, J. T. Nasher, G. Natarajan, I. Negoi, J. W. Ngunjiri, C. T. Nguyen, Q. L. Nguyen, T. H. Nguyen, G. Nguyen, M. Nguyen, E. Nichols, D. N. A. Ningrum, V. M. Nong, J. J. N. Noubiap, F. A. Ogbo, I.-H. Oh, A. Okoro, A. T. Olagunju, H. E. Olsen, B. O. Olusanya, J. O. Olusanya, K. Ong, J. N. Opio, E. Oren, A. Ortiz, M. Osman, E. Ota, M. Pa, R. E. Pacella, S. Pakhale, A. Pana, B. K. Panda, S. Panda-Jonas, C. Papachristou, E.-K. Park, S. B. Patten, G. C. Patton, D. Paudel, K. Paulson, D. M. Pereira, F. Perez-Ruiz, N. Perico, A. Pervaiz, M. Petzold, M. R. Phillips, D. M. Pigott, C. Pinho, D. Plass, M. A. Pletcher, S. Polinder, M. J. Postma, F. Pourmalek, C. Purcell, M. Qorbani, B. P. A. Quintanilla, A. Radfar, A. Rafay, V. RahimiMovaghar, M. H. U. Rahman, M. Rahman, R. K. Rai, C. L. Ranabhat, Z. Rankin, P. C. Rao, G. K. Rath, S. Rawaf, S. E. Ray, J. Rehm, R. C. Reiner, M. B. Reitsma, G. Remuzzi, S. Rezaei, M. S. Rezai, M. B. Rokni, L. Ronfani, G. Roshandel, G. A. Roth, D. Rothenbacher, G. M. Ruhago, R. Sa, S. Saadat, P. S. Sachdev, N. Sadat, M. Safdarian, S. Safi, S. Safiri, R. Sagar, R. Sahathevan, J. Salama, P. Salamati, J. A. Salomon, A. M. Samy, J. R. Sanabria, M. D. Sanchez-Niño, D. Santomauro, I. S. Santos, M. M. Santric Milicevic, B. Sartorius, M. Satpathy, M. I. Schmidt, I. J. C. Schneider, S. Schulhofer-Wohl, A. E. Schutte, D. C. Schwebel, F. Schwendicke, S. G. Sepanlou, E. E. ServanMori, K. A. Shackelford, S. Shahraz, M. A. Shaikh, M. Shamsipour, M. Shamsizadeh, J. Sharma, R. Sharma, J. She, S. Sheikhbahaei, M. Shey, P. Shi, C. Shields, M. Shigematsu, R. Shiri, S. Shirude, I. Shiue, H. Shoman, M. G. Shrime, I. D. Sigfusdottir, N. Silpakit, J. P. Silva, J. A. Singh, A. Singh, E. Skiadaresi, A. Sligar, D. L. Smith, A. Smith, M. Smith, B. H. A. Sobaih, S. Soneji, R. J. D. Sorensen, J. B. Soriano, C. T. Sreeramareddy, V. Srinivasan, J. D. Stanaway, V. Stathopoulou, N. Steel, D. J. Stein, C. Steiner, S. Steinke, M. A. Stokes, M. Strong, B. Strub, M. Subart, M. B. Sufiyan, B. F. Sunguya, P. J. Sur, S. Swaminathan, B. L. Sykes, R. Tabarés-Seisdedos, S. K. Tadakamadla, K. Takahashi, J. S. Takala, R. T. Talongwa, M. R. Tarawneh, M. Tavakkoli, N. Taveira, T. K. Tegegne, A. Tehrani-Banihashemi, M.-H. Temsah, A. S. Terkawi, J. S. Thakur, O. Thamsuwan, K. R. Thankappan, K. E. Thomas, A. H. Thompson, A. J. Thomson, A. G. Thrift, R. Tobe-Gai, R. ToporMadry, A. Torre, M. Tortajada, J. A. Towbin, B. X. Tran, C. Troeger, T. Truelsen, D. Tsoi, E. M. Tuzcu, S. Tyrovolas, K. N. Ukwaja, E. A. Undurraga, R. Updike, O. A. Uthman, B. S. C. Uzochukwu, J. F. M. van Boven, T. Vasankari, N. Venketasubramanian, F. S. Violante, V. V. Vlassov, S. E. Vollset, T. Vos, T. Wakayo, M. T. Wallin, Y.-P. Wang, E. Weiderpass, R. G. Weintraub, D. J. Weiss, 
A. Werdecker, R. Westerman, B. Whetter, H. A. Whiteford, T. Wijeratne, C. S. Wiysonge, B. G. Woldeyes, C. D. A. Wolfe, R. Woodbrook, A. Workicho, D. Xavier, Q. Xiao, G. Xu, M. Yaghoubi, B. Yakob, Y. Yano, M. Yaseri, H. H. Yimam, N. Yonemoto, S.-J. Yoon, M. Yotebieng, M. Z. Younis, Z. Zaidi, M. E. S. Zaki, E. A. Zegeye, Z. M. Zenebe, T. A. Zerfu, A. L. Zhang, X. Zhang, B. Zipkin, S. Zodpey, A. D. Lopez and C. J. L. Murray (2017). "Global, regional, and national age-sex specific mortality for 264 causes of death, 1980-2016: a systematic analysis for the Global Burden of Disease Study 2016." The Lancet 390(10100): 1151-1210.

Nair, P. (2018). Delivery in government hospitals free but not exactly. The Times of India.

Nandi, S., R. Dasgupta, S. Garg, D. Sinha, S. Sahu and R. Mahobe (2016). "Uncovering coverage: utilisation of the universal health insurance scheme, Chhattisgarh by women in slums of Raipur." Indian journal of gender studies 23(1): 43-68.

National Sample Survey Organisation (2004). Morbidity, Health Care and the Condition of the Aged (Round 60, Schedule 25). M. o. S. a. P. I. Government of India.

Newhouse, J. P. (1993). Free for all?: lessons from the RAND health insurance experiment, Harvard Univ Pr.

OECD. (2020). "Purchasing power parities (PPP) (indicator)." Retrieved January 6, 2020.

Oxfam (2008). Health insurance in low-income countries: Where is the evidence that it works? O. B. Report.

Patel, K. and M. Rushefsky (2019). Healthcare politics and policy in America, Routledge.

Pendzialek, J. B., D. Simic and S. Stock (2016). "Differences in price elasticities of demand for health insurance: a systematic review." The European Journal of Health Economics 17(1): 5-21.

Prabhavathi, P. C. and N. Naveena (2014). "An Analysis of Poverty in Karnataka: A Study." IOSR Journal Of Humanities And Social Science 19(3): 72-31.

Prinja, S., P. Bahuguna, I. Gupta, S. Chowdhury and M. Trivedi (2019). "Role of insurance in determining utilization of healthcare and financial risk protection in India." PLOS ONE 14(2): e0211793.

Rajasekhar, D., E. Berg, M. Ghatak, R. Manjula and S. Roy (2011). "Implementing Health Insurance: The Rollout of Rashtriya Swasthya Bima Yojana in Karnataka." Economic and Political Weekly 46(20): 56-63. 
RSBY. (2018). "You are viewing: Karnataka; Enrollment of Beneficiaries." from https://web.archive.org/web/20180131035129/http://www.rsby.gov.in/Statewise.aspx?state= $\underline{29}$.

Shahrawat, R. and K. D. Rao (2012). "Insured yet vulnerable: out-of-pocket payments and India's poor." Health Policy and Planning 27(3): 213-221.

Sommers, B. D., K. Baicker and A. M. Epstein (2012). "Mortality and Access to Care among Adults after State Medicaid Expansions." New England Journal of Medicine 367(11): 1025-1034.

Sommers, B. D. and A. M. Epstein (2010). "Medicaid expansion-the soft underbelly of health care reform?" New England Journal of Medicine.

Sommers, B. D., S. K. Long and K. Baicker (2014). "Changes in mortality after massachusetts health care reform: A quasi-experimental study." Annals of Internal Medicine 160(9): 585-593.

Sood, N., E. Bendavid, A. Mukherji, Z. Wagner, S. Nagpal and P. Mullen (2014). "Government health insurance for people below poverty line in India: quasi-experimental evaluation of insurance and health outcomes." BMJ 349: g5114.

Sorensen, A. T. (2006). "Social learning and health plan choice." The Rand journal of economics 37(4): 929-945.

Thornton, R. L., L. E. Hatt, E. M. Field, M. Islam, F. Solís Diaz and M. A. González (2010). "Social security health insurance for the informal sector in Nicaragua: a randomized evaluation." Health Economics 19(S1): 181-206.

Trivedi, M. and D. B. Saxena (2013). "Third Angle of RSBY: Service Providers' Perspective to RSBY-operational Issues in Gujarat." Journal of family medicine and primary care 2(2): 169-172.

World Health Organization (2021). Global Health Expenditure Database. 